NBER WORKING PAPER SERIES

\title{
WHO BEARS THE COST OF RECESSIONS? THE ROLE OF HOUSE PRICES AND HOUSEHOLD DEBT
}

\author{
Atif Mian \\ Amir Sufi \\ Working Paper 22256 \\ http://www.nber.org/papers/w22256 \\ NATIONAL BUREAU OF ECONOMIC RESEARCH \\ 1050 Massachusetts Avenue \\ Cambridge, MA 02138 \\ May 2016
}

This manuscript is prepared as a chapter for the Handbook of Macroeconomics: Volume 2. The research presented here was supported by funding from the Initiative on Global Markets at Chicago Booth, the Fama-Miller Center at Chicago Booth, and Princeton University. We thank Ruediger Bachmann, John B. Taylor, Harald Uhlig, and seminar participants at the Handbook of Macroeconomics conference at the University of Chicago for valuable feedback. We thank Jung Sakong and Xiao Zhang for excellent research assistance. Any opinions, findings, or conclusions or recommendations expressed in this material are those of the authors and do not necessarily reflect the view of any other institution. Mian: (609) 258 6718, atif@princeton.edu; Sufi: (773) 702 6148,amir.sufi@chicagobooth.edu The views expressed herein are those of the authors and do not necessarily reflect the views of the National Bureau of Economic Research.

NBER working papers are circulated for discussion and comment purposes. They have not been peer-reviewed or been subject to the review by the NBER Board of Directors that accompanies official NBER publications.

(C) 2016 by Atif Mian and Amir Sufi. All rights reserved. Short sections of text, not to exceed two paragraphs, may be quoted without explicit permission provided that full credit, including () notice, is given to the source. 
Who Bears the Cost of Recessions? The Role of House Prices and Household Debt

Atif Mian and Amir Sufi

NBER Working Paper No. 22256

May 2016

JEL No. E21,E32,E44,E51

\begin{abstract}
$\underline{\text { ABSTRACT }}$
This chapter reviews empirical estimates of differential income and consumption growth across individuals during recessions. Most existing studies examine the variation in income and consumption growth across individuals by sorting on ex ante or contemporaneous income or consumption levels. We build on this literature by showing that differential shocks to household net worth coming from elevated household debt and the collapse in house prices play an underappreciated role. Using zip codes in the United States as the unit of analysis, we show that the decline in numerous measures of consumption during the Great Recession was much larger in zip codes that experienced a sharp decline in housing net worth. In the years prior to the recession, these same zip codes saw high house price growth, a substantial expansion of debt by homeowners, and high consumption growth. We discuss what models seem most consistent with this striking pattern in the data, and we highlight the increasing body of macroeconomic evidence on the link between household debt and business cycles. Our main conclusion is that housing and household debt should play a larger role in models exploring the importance of household heterogeneity on macroeconomic outcomes and policies.
\end{abstract}

\author{
Atif Mian \\ Princeton University \\ Bendheim Center For Finance \\ 26 Prospect Avenue \\ Princeton, NJ 08540 \\ and NBER \\ atif@princeton.edu \\ Amir Sufi \\ University of Chicago \\ Booth School of Business \\ 5807 South Woodlawn Avenue \\ Chicago, IL 60637 \\ and NBER \\ amir.sufi@chicagobooth.edu
}




\section{Introduction}

Severe recessions are characterized by a large decline in household consumption. Consumption in real terms in the United States fell by almost 3\% from the second quarter of 2008 to the second quarter of 2009. Consumption fell from 1929 to 1933 of the Great Depression by 18\%. From 2008 to 2011 , consumption fell by more than $5 \%$ in seven countries in the European Union, and by just less than 5\% in Ireland and the United Kingdom.

Given the importance of consumption in household welfare, these sharp declines help explain why the study of recessions is a central pursuit of macroeconomics. One approach is to focus on the causes and implications of the aggregate decline in consumption. We believe, however, that an important pursuit of macroeconomic research should be to understand the distribution of the consumption decline across individuals. As the title of our chapter suggests, we want to focus on the question: who bears the cost of recessions? More specifically, which households see the largest drop in consumption during economic downturns?

This is an important question for several reasons. First, there has been an ongoing discussion within macroeconomics on the welfare cost of aggregate fluctuations, a debate instigated by the provocative exercise in Lucas (1987). Research since Lucas (1987) has shown that the distribution of income and consumption losses across individuals during recessions is an important factor in whether business cycles have large welfare consequences. For example, both Krebs (2007) and Krusell, Mukoyama, Şahin, and Smith (2009) use models with heterogeneity across households to argue that the welfare consequences of aggregate fluctuations are an order of magnitude larger than those calculated by Lucas (1987). Understanding both the distribution of consumption losses and their persistence helps reveal how harmful economic downturns are.

Another important reason to study the distribution of consumption growth during recessions is to evaluate the financial system. One of the central roles of the financial system is to efficiently allocate risk. A large body of research has focused on whether the data are consistent with full consumption risk sharing, when an individuals consumption is not a direct function of idiosyncratic shocks received by the individual (e.g., Cochrane (1991)). A focus on recessions is useful because

it helps us evaluate whether risk-sharing is present during times of steep declines in aggregate consumption. If it is not, then further analysis of the financial system and government insurance 
provision is warranted.

There are also important asset pricing implications from examining the distribution of consumption growth during recessions. Recessions tend to be times when asset prices decline. In representative agent consumption-based asset pricing models, a security's payments during recessions (i.e., periods when marginal utility of consumption is high) is a central determinant of the value of the security. But as many researchers have noted, financial securities such as corporate equity are held disproportionately by high income, wealthy individuals. Fluctuations in aggregate consumption may not be as useful in pricing financial assets as the fluctuations in consumption of individuals that tend to hold financial assets (e.g., Mankiw and Zeldes (1991), Malloy, Moskowitz, and Vissing-Jørgensen (2009)). Therefore, a central question in valuing financial assets is whether the consumption of individuals that hold financial assets is more or less cyclical than the rest of the population.

This review is split into three main parts. In the first part, we review the empirical literature on the cyclicality of income and consumption across individuals. We detail the exact time periods studied, data used, and conclusions of each study. Our primary focus is on research examining the cross-sectional differences in income growth and consumption growth across individuals during recessions. But we also cover ancillary empirical studies on consumption-risk sharing and the evolution of consumption and income inequality over time. These latter two areas of research are related both from a theoretical and methodological perspective.

It becomes clear in our review of the literature that the role of wealth shocks, and in particular wealth shocks associated with housing, is largely absent. In the second section of this chapter, we present empirical evidence on the importance of shocks to household net worth in explaining cross-sectional differences across U.S. zip codes in consumption growth during the Great Recession. We begin this section by discussing both the advantages and disadvantages of zip code level data. As a preview, the main advantage of zip code level data is the ability to match high quality administrative data on income, consumption, wealth, and demographics that naturally add up to aggregates used by most macroeconomists. The main disadvantage is that we can only estimate key parameters such as the elasticity of consumption with respect to net worth shocks at a slightly aggregated level.

Using zip code level data, we show that variation in the decline in net worth coming from the 
collapse in house prices from 2006 to 2009, what we call the housing net worth shock, is a powerful predictor of consumption growth across zip codes. We utilize zip level administrative data on car ownership, new car purchases, and boat ownership, in addition to survey based measures of the number of individuals living in a housing unit. By all of these measures, zip codes with a more negative housing net worth shock saw substantially lower consumption growth during the Great Recession. We also show that births declined by substantially more in zip codes hit harder by the housing crash.

The housing net worth shock in a zip code can be decomposed into the decline in house prices in the zip code, and the ex ante exposure of the zip code's wealth to a decline in house prices. We find that both matter. Prior to the recession, zip codes with a large exposure to the housing collapse saw a larger increase in house prices, homeowner borrowing, and consumption.

Motivated by these empirical results, we then review models of aggregate economic fluctuations that can best explain the link between house price shocks and the cross-sectional differences in consumption growth. While our empirical results focus mostly on the Great Recession, we also highlight macroeconomic evidence showing a strong link between household debt, house prices, and business cycles across many countries and time periods.

It is important also to note what this review chapter does not cover. Probably the biggest absence is a detailed review of quantitative macroeconomic models with heterogeneity across households (e.g., the literature started by Bewley (1977) and Huggett (1993) among others). We cover some of this research as it has an important empirical component, but we do not review it comprehensively. This literature has shaped our thinking in important ways, and our exclusion of this excellent body of research reflects the fact that there is already a must-read review of this literature by Heathcote, Storesletten, and Violante (2009). We highly recommend reading their review as a complement to this one.

\section{Who Bears Recession Risk? Existing Research}

\subsection{Categorizing the literature}

As noted in the introduction, the cyclicality of consumption and income across the distribution of households in the economy plays a crucial role in important questions in macroeconomics. A 
critical input into any model of cross-sectional heterogeneity in risk exposure is a set of basic facts. As Guvenen, Ozkan, and Song (2014) put it:

What is common to all of these theoretical and quantitative investigations is that they need to rely on empirical studies to first establish the basic facts regarding the cyclical nature of income risk. Unfortunately, apart from a few important exceptions discussed below, there is little empirical work on this question, largely because of data limitation.

Our goal in this section is to review the empirical evidence on the cyclical nature of both income and consumption risk. While Guvenen, Ozkan, and Song (2014) are correct that the evidence is limited, there are a number of important studies that can be used as a launching pad for further research.

There are five dimensions on which the extant literature can be categorized. First, does the study examine the cyclicality of income growth or consumption growth? Second, what data set is employed? Third, what time period is examined, and more specifically, does the study focus on one recession or a longer time series of cycles? Fourth, on what dimension are households sorted in the cross-section when examining income growth or consumption growth across the distribution? And finally, does the study sort households based on ex ante characteristics, contemporaneous placement in the income or consumption distribution, or shocks received during the recession?

It is this last dimension around which we organize the rest of this section. In our view, the ideal empirical setting is one in which households can be sorted on some ex ante characteristic, and then tracked across cycles. More formally, define some period $\tau=0$ to $\tau=T$ as an aggregate episode such as an expansion or recession. Following Guvenen, Ozkan, and Song (2014), the empirical object of interest is:

$$
f\left(H_{-1}^{i}\right) \equiv E\left[y_{T}^{i}-y_{0}^{i} \mid H_{-1}^{i}\right]
$$

where $H_{-1}^{i}$ is a characteristic of individual or group $i$ measured before the episode in question and $y_{\tau}^{i}$ is $\log$ consumption or $\log$ income for individual or group $i$ at $\tau .{ }^{1}$ The empirical object $f\left(H_{-1}^{i}\right)$ can be estimated in a flexible manner based on the number of groups.

For example, Guvenen, Ozkan, and Song (2014) examine four recession periods between 1978

\footnotetext{
${ }^{1}$ To minimize notation, $y_{\tau}^{i}$ represents log average consumption or log average income in the group whenever $i$ is a group instead of an individual.
} 
and 2013, and their primary specification uses average income over the five years prior to the recession as $H_{-1}^{i}$. They sort individuals into percentile bins based on this measure of $H_{-1}^{i}$, and they plot $y_{T}^{i}-y_{0}^{i}$ during each recession for each bin, where $y$ is a measure of income. Such a plot allows us to see whether individuals with higher ex ante income levels see larger or smaller declines in income growth during recessions. As Guvenen, Ozkan, and Song (2014) note, researchers must be cautious in estimating object 1 when $H_{-1}^{i}$ is income or consumption. It is likely that income and consumption have mean-reverting properties. As a result, an estimation strategy that sorts on ex ante income and looks at subsequent income growth will tend to find negative effects of $e x$ ante income on income growth. For example, one is likely to find that high income individuals see larger declines in income growth. But in the presence of a mean-reverting income process, such a result would be partially mechanical.

Notice that availability of panel data is crucial for such an exercise. It is only possible if one can track the same households over time. We refer to the literature that estimates the object in 1 as sorting on ex ante characteristics.

A related technique exploits panel data but sorts not on ex ante household characteristics but instead on shocks received during the recession. For example, a common assumption in quantitative models of heterogeneity is that some households become unemployed, and the probability of becoming unemployed is higher in recessions (e.g., Krusell and Smith (1999)). A natural empirical object of interest in such a model is the decline in consumption among those individuals becoming unemployed during the recession:

$$
f\left(S_{T}^{i}\right) \equiv E\left[y_{T}^{i}-y_{0}^{i} \mid S_{T}^{i}\right]
$$

where $S_{T}^{i}$ is a shock received during the recession such as unemployment or a decline in wealth. Once again, panel data is required to estimate this object. We refer to the literature that estimates the object in 2 as sorting on contemporaneous shocks.

Unfortunately, estimation of the objects in 1 and 2 requires panel data which is not widely available, especially on consumption. As a result, a third technique is to rely on repeated crosssections, where households in each cross-section are sorted into percentiles of either the income or consumption distribution. This is common in studies, for example, that rely on income data from 
the Internal Revenue Service. Letting $p$ be a percentile group of the distribution, these studies typically follow the object $y_{\tau}^{p}$ across time.

The drawback of this approach is that the evolution of $y_{\tau}^{p}$ over time depends both on changes in $y$ for households that stay within group $p$, and changes in the composition of households in group $p$. Following Perri and Steinberg (2012), the change from any period $\tau=0$ to $\tau=T$ in group $p$ is:

$$
y_{T}^{p}-y_{0}^{p}=\alpha\left(y_{T}^{p_{-} \text {stay }}-y_{0}^{p_{-} \text {stay }}\right)+(1-\alpha)\left(y_{T}^{p_{-} \text {in }}-y_{0}^{p_{-} \text {out }}\right)
$$

The growth in an outcome for the $p$ percentile of the distribution is a weighted average of the growth in the outcome for households that stay in the percentile group $\left(y_{T}^{p_{-} \text {stay }}-y_{0}^{p_{\text {sstay }}}\right)$ and the

compositional change in the percentile group $p\left(y_{T}^{p_{\text {_in }}}-y_{0}^{p_{-} o u t}\right)$. Notice that the first term of this expression is almost identical to the object of interest in 1 where the sorting variable is the percentile of the distribution ex ante. We refer to research following 3 as following a repeated cross-section approach.

One obvious question is how good a proxy for object 1 is object 3 . This depends primarily on movements across the distribution during episode being examined. To our knowledge, there is no comprehensive evaluation of this technique in the literature. The closest we could find is Perri and Steinberg (2012), who highlight different patterns in consumption growth depending on whether individuals or percentiles are tracked over time. We will discuss Perri and Steinberg (2012) in more detail below.

A final group of studies we discuss below are those that use empirical moments from data to calibrate quantitative macroeconomic models of household heterogeneity. As mentioned in the introduction, we do not do a comprehensive review of this literature. But many of these studies contain significant empirical work that is related to the core questions of this review.

\subsection{Sorting on ex ante characteristics}

The gold standard for evaluating the cross-sectional implications of recessions for earnings is the study by Guvenen, Ozkan, and Song (2014). Using a very large data set from the U.S. Social Security Administration, they are able to track the earnings of individuals from 1978 to 2011, which allows analysis of four recessions. Their main data set focuses on US working-age males over 
this time period. Given the panel structure of the data, they are able to estimate object 1 explicitly by sorting individuals into income bins prior to each recession and expansion.

The exact dates they use for the four recession periods are: 1979 to 1983, 1990 to 1992, 2000 to 2002 , and 2007 to 2010 . They estimate a slight variation of object 1 above in order to avoid problems associated with those with zero earnings. The actual function they estimate is:

$$
\log \left(E\left[y_{T}^{i} \mid H_{-1}^{i}\right]\right)-\log \left(E\left[y_{0}^{i} \mid H_{-1}^{i}\right]\right)
$$

Figure 13 in their study reveals the central finding with respect to recessions. In all four recessions, there is a positive relation between ex ante income and income growth from the 10th percentile of the distribution to the 70th percentile. For all recessions except for 2000 to 2002, the positive relation continues to the 90th percentile. That is, for the majority of the income distribution and for all recessions, lower income individuals suffer more during recessions as measured by income growth. Notice this effect is probably understated given that mean-reversion would bias the coefficient in the opposite direction.

The pattern is less consistent at the upper tail of the distribution. The two latest recessions look remarkably similar at the very top of the income distribution. Individuals in the top $10 \%$ of the ex ante income distribution see the largest decline in income in the entire population. At the 99th percentile, income drops by a stunning 30\%. This pattern is not present in the two earlier recessions. In sum, from the 10th percentile to 90th percentile of the ex ante income distribution, lower income individuals see a bigger decline in income during recessions. The results are less definitive above the 90 th percentile, with the last two recessions showing the biggest decline among the very rich.

Perri and Steinberg (2012) use panel data from the Panel Study of Income Dynamics (PSID) to study disposable income growth during the 2007 to 2009 recession across the income distribution. They first show that the bottom 20 percent of the income distribution saw a sharp decline in earnings, falling by 30 percent relative to the median over the course of the recession. However, they also show that redistribution through taxes and transfer programs helped offset the decline in earnings. Disposable income, after taking into account taxes and transfers, declined the same amount for the rest of the population and households in the bottom 20 percent of the income 
distribution.

The above findings are based on comparing income for the bottom 20 percent of the income distribution in 2006 and 2008. But as mentioned above, a problem with such a methodology is that there may be significant compositional changes in the households in the bottom 20 percent. The study by Perri and Steinberg (2012) is one of the few that discusses this problem, and compares estimates when taking into account the compositional change. They show that $75 \%$ of the individuals in the bottom $20 \%$ of the income distribution in 2008 were in the bottom $20 \%$ in 2006 . They also show that the households that enter the bottom $20 \%$ of the income distribution from 2006 to 2008 see a dramatic $53.4 \%$ decline in disposable income. Households that stayed in the bottom $20 \%$ saw a decline of $2 \%$ in disposable income. Households that left the bottom $20 \%$ from 2006 to 2008 saw a $110 \%$ rise in disposable income.

Heathcote and Perri (2015) utilize data from the Consumer Expenditure Survey (CEX) and the Panel Study of Income Dynamics (PSID) to study the relation between ex ante household wealth and the change in consumption rates, or the consumption to income ratio, during the recession of 2007 to 2009. The primary focus is on the PSID, and they sort households in year $t$ based on the ratio of wealth to average consumption in years $t$ and $t+2$. Because the denominator includes future consumption, the analysis does not strictly sort on ex ante characteristics. Nonetheless, the spirit of the exercise is to sort on individuals on their wealth to consumption ratio prior to the recession.

Heathcote and Perri (2015) find a larger drop in the consumption rate for poor households from 2006 to 2008. The consumption rate out of income drops by almost 10 percentage points for the lower half of the wealth distribution, and only 4 percentage points for the upper half. The authors interpret the larger drop in consumption rates of the poor as evidence consistent with a larger rise in a precautionary savings motive. They conduct tests showing that the wealth shock from 2006 to 2008 was larger for rich households, and income prospects deteriorated equally for the rich and poor. Both of these factors strengthen the conclusion that the larger drop in consumption rates for poor households was due to precautionary savings.

Another strand of research focuses on variation in the cyclicality of consumption growth across households based on whether the household holds financial assets. The motivation behind this research is a canonical model of consumption-based asset pricing, where the key determinant of 
asset prices is consumption risk. Isolating who bears risk during recessions is not the central question of this literature. Nonetheless, it offers insight by showing how consumption growth is correlated with stock returns across households that own and do not own stocks.

Mankiw and Zeldes (1991) use the PSID from 1970 to 1984, and sort households based on whether they report a positive market value of stock holdings in 1984. Unfortunately, the PSID first asked this question in 1984, and so the authors must use an ex post measure of stock holding rather than an ex ante measure. They find that stockholders' consumption is more volatile and more highly correlated with the stock market than households that do not hold stock. They argue that this higher correlation "may be crucial to an ultimate resolution of this puzzle and other asset pricing anomalies." Households that hold stocks tend to have higher income and higher wealth than those that do not; therefore, this finding suggests that the cyclicality of consumption is highest for richer households.

A more recent paper by Malloy, Moskowitz, and Vissing-Jørgensen (2009) uses the CEX from 1982 to 2004 to test whether long-run consumption growth of households who hold financial assets is more sensitive to asset price fluctuations. The CEX is typically used in the literature as a repeated cross-section of respondents. However, there is a panel element because households are surveyed for four consecutive quarters. Malloy, Moskowitz, and Vissing-Jørgensen (2009) utilize the panel dimension by calculating consumption growth for a group of households from period $t$ to $t+1$ as the average over each household's consumption growth from $t$ to $t+1$. The resulting group-level consumption growth rates have both a panel and repeated cross-sectional dimension, because households in the sample leave after four quarters.

Using consumption growth of stockholders versus non-stockholders, the authors first show that stockholder consumption growth has a higher sensitivity (or "beta") to aggregate consumption growth, especially at long horizons. They conclude based on this finding that "stockholders bear a disproportionate amount of aggregate consumption risk relative to nonstockholders and this burden increases in the long run ...". Further, the authors find that the consumption growth of stockholders is more correlated with asset returns. Malloy, Moskowitz, and Vissing-Jørgensen (2009) estimate Euler equations using asset returns and the consumption growth of stockholders, and they find that estimated risk aversion is much lower compared to using aggregate consumption growth. 


\subsection{Repeated Cross-Section Approach}

Only a few of the existing data sets on income and consumption cover a panel of individuals that one can track over an extended period of time. As a result, many researchers use a "percentilesorting" methodology, as described above in Section 2.1. A classic example of this technique is the series of studies by Piketty, Saez, and Zucman using IRS tax returns to measure the evolution of income and wealth inequality in the United States (Piketty and Saez (2003), Piketty and Saez (2006) Piketty and Zucman (2014), Saez and Zucman (2014), and Saez (2015)). The primary focus of these studies is long run trends in income and wealth inequality, not isolating who bears the cost of recessions.

However, Saez (2015) uses the same data to try to address the cyclicality of income across different groups. For example, he shows that average real income growth from 1993 to 2013 was $15.1 \%$, and $62.4 \%$ for the top $1 \%$ of the distribution. Recall that this latter figure takes the income of the top 1\% in 2013 and compares it to the income of the top 1\% in 1993 - it is not based on the same individuals. Saez then shows that the income of the top $1 \%$ falls considerably more in recessions, and increases significantly more during expansions. For example, the top 1\% saw a decline in income of $31 \%$ and $36 \%$ during the 2001 recession and the Great Recession, respectively. The corresponding growth rates for average income are $-12 \%$ and $-17 \%$. These figures include capital gains income, but the pattern is also present excluding capital gains, albeit less pronounced. This finding using repeated cross-sectional analysis confirms the panel data analysis of earnings in Guvenen, Ozkan, and Song (2014): income fell the most for very high income individuals during the 2001 and the 2007 to 2009 recessions.

Parker and Vissing-Jorgensen (2010) use the IRS data to show that more cyclical income growth of high income individuals is a recent phenomenon. They measure income as real pre-tax, pretransfer income excluding capital gains. They examine the cross-sectional variation in income growth across the income distribution during recessions and expansions, and they find that the top $1 \%$ of the income distributions saw sharp declines during the last three recessions. However, the five recessions prior to the last three did now show this pattern. The authors also calculate an 
income "beta", which comes from the estimation of the following equation:

$$
\Delta \ln Y_{i, t+1}=\alpha_{i}+\beta_{i} \Delta \ln Y_{t+1}+\epsilon_{i, t+1}
$$

This specification tells us whether income of group $i$ loads more heavily on changes in aggregate income. Parker and Vissing-Jorgensen (2010) show that the top 1\% of the income distribution has a much higher $\beta$ from 1982 to 2008 than in previous years. Further, the higher cyclicality of income of the very rich is robust to alternative measures of income from the Census.

Parker and Vissing-Jorgensen (2010) also examine the cyclicality of consumption across the ex ante expenditure distribution. They utilize the CEX and a methodology that is similar to Malloy, Moskowitz, and Vissing-Jørgensen (2009). More specifically, they first sort households into groups based on expenditure level in quarter $q$, and they calculate the quarterly consumption growth for the group as the average of the quarterly growth rates of the households within the group. Recall that the CEX allows for such a calculation because households are surveyed for four consecutive quarters. They then calculate annual consumption growth for each group as the sum of the four quarterly growth rate figures. In this manner, the consumption growth measure has both a repeated cross-section and panel dimension.

The authors estimate a similar equation as the income specification above to find a consumption $\beta$ of each group on aggregate consumption and aggregate income. They find that the top $5 \%$ of the expenditure distribution has more cyclical consumption than the rest of the population. They find higher cyclicality using a number of measures of including aggregate pre- and post-tax income from NIPA or aggregate consumption from NIPA. As with Malloy, Moskowitz, and Vissing-Jørgensen (2009), the measures of consumption used by Parker and Vissing-Jorgensen (2010) are primarily expenditures on non-durable goods and services. Expenditures on durable goods, for example, are not included.

Meyer and Sullivan (2013a) focus on consumption inequality from 2000 to 2011 using the CEX. They convert expenditures into consumption for vehicles using a service flow equivalent, and they exclude housing outlays and spending on education. Their analysis is a pure repeated cross-section; they do not take advantage of the panel element of the data. For each year, they sort households into percentiles based on the level of consumption, and they plot the log difference for each group relative 
to 2000. They find more cyclical consumption in the high consumption groups. For example, for the 90 th percentile, consumption increased by $20 \%$ from 2000 to 2007 , and then subsequently fell $6 \%$ from 2007 to 2009 . In contrast, consumption at the median increased by $16 \%$ from 2000 to 2007 before dropping by $4 \%$ from 2007 to 2009 .

Most of the extant research on consumption growth variation across households relies on either the CEX or the PSID. Cynamon and Fazzari (2014) is an exception. They focus on consumption of the bottom $95 \%$ and top $5 \%$ of the income distribution, and they track these two groups over time. They estimate consumption by each of these two groups by estimating income and saving rates, and using the difference as the consumption rate. Their methodology takes aggregate savings and uses micro-economic estimates of savings rates to distribute savings to each of the two groups. Similarly, they distribute income to the two groups based on information from the Congressional Budget Office and the Piketty and Saez IRS data sets. By construction, total income, saving, and consumption adds up to the aggregates from NIPA.

Cynamon and Fazzari (2014) show that the consumption to income ratio of the bottom $95 \%$ of the income distribution fell sharply during the Great Recession from $92 \%$ in 2007 to $87 \%$ in 2010. The consumption to income ratio rose sharply for the top $5 \%$ of the income distribution, which the authors argue is evidence that the top 5\% smoothed consumption (income fell but consumption remained constant). The consumption to income ratio of the top $5 \%$ also increased substantially during the 2001 recession. Looking at the level of consumption, the authors show that consumption during the Great Recession deviated sharply from trend for both groups, with the magnitude of the decline being slightly larger for the bottom $95 \%$ of the income distribution.

\subsection{Sorting on Shocks Received in the Recession}

Unemployment increases sharply in recessions. For example, Davis and von Wachter (2011) show that the quarterly layoff rate rises by 129 basis points from 1990Q2 to 1991Q2, 85 basis points from 2000Q2 to 2001Q4, and 208 basis points from 2007Q3 to 2009Q1. Rather than sorting on ex ante characteristics, Davis and von Wachter (2011) sort individuals based on exposure to a mass layoff wave during recessions.

More specifically, the authors regard a worker as "displaced" in year $y$ if he separates from his employer in $y$ and the employer experiences a mass-layoff in $y$. A mass-layoff event is one where 
the employer meets the following criteria: 50 or more employees in year $y-2$, a contraction of employment between 30 and $99 \%$ from $y-2$ to $y$, employment in $y-2$ is no more than $130 \%$ of employment in year $y-3$, and employment in $y+1$ is less than $90 \%$ of employment in $y-2$. They utilize longitudinal SSA records from 1974 to 2008 to measure earnings, which is the same data used by Guvenen, Ozkan, and Song (2014). Given the sample period, there are three main recession periods they analyze: the early 1980s, the early 1990s and the early 2000s.

The central finding is that individuals losing a job during a mass layoff in a high unemployment environment (greater than $8 \%$ ) lose 2.8 years of predisplacement earnings in present value terms. The loss is 1.4 year of predisplacement earnings if an individual loses a job in a mass layoff event when the unemployment rate is below $6 \%$. The large loss of income when losing a job during a high unemployment rate environment is supported by a number of other studies. For example, Jacobson, LaLonde, and Sullivan (1993) show that job displacement in Pennsylvania in the early 1980s led on average to a near-term earnings loss of more than 50\%. Losses persist for at least 10 years (Sullivan and Von Wachter (2009)). Topel (1991) finds that workers displaced from 1979 to 1984 who can find a new job face a 14\% reduction in earnings. Davis and von Wachter (2011) have data only through 2008, and are therefore unable to measure the long-term consequences of the Great Recession. However, as they note, the existing research "suggests that workers who have experienced job displacement events since 2008 are likely to suffer severe and persistent earnings losses."

A related line of research examines the effects of graduating from college during a recession. Kahn (2010) uses data from the National Longitudinal Survey of Youth on students that graduated from college between 1979 and 1989. She uses both variation in the national unemployment rate and the state unemployment rates to identify the effect of graduation in a weak economy on wages. She finds "large, negative wage effects of graduating in a worse economy which persist for the entire period studied." More specifically, she finds an initial wage loss of 6 to $7 \%$ for a 1 percentage point increase in the unemployment rate. The wage loss dissipates over time, but wages remain $2.5 \%$ lower even 15 years after graduation. A related study by Oreopoulos, von Wachter, and Heisz (2012) examines Canadian data. They find that a rise in unemployment rates by 5 percentage point implies an initial loss in earnings of about $9 \%$ that halves within 5 years and finally fades to 0 by 10 years. 
Recessions are also times when there are substantial shocks to both housing and financial wealth. Such shocks typically have a strong cross-sectional component, given substantial crosssectional variation across households in exposure to such shocks. Mian, Rao, and Sufi (2013) exploit cross-sectional variation across U.S. geographic units-counties or zip codes-in the exposure to housing net worth shocks during the Great Recession. The authors define the housing net worth as the decline in household net worth coming from the collapse in house prices. The variation across the country is large: the housing net worth shock was almost $-50 \%$ in the bottom decile of county distribution, but $0 \%$ in the top. They show that the decline in consumer spending was larger in counties with a more negative housing net worth shock. Using zip-code level data on auto purchases, they also show that the marginal propensity to spend out of housing wealth is substantially larger for lower income and higher household leverage zip codes. Kaplan, Mitman, and Violante (2015) and Stroebel and Vavra (2014) use a different data source and find results similar to Mian, Rao, and Sufi (2013); consumption growth during the Great Recession is strongly correlated with house price growth across U.S. cities. In the analysis below, we show a strong state-level correlation between house price growth and personal consumption growth during the Great Recession using new data from the Bureau of Economic Analysis.

Mian and Sufi (2010) sort counties by the change in the household debt to income ratio from 2002 to 2006, and then examine how the decline in new auto purchases and residential investment during the Great Recession is related to the previous increase in household debt. They find a negative relation: counties with large increases in the household debt to income ratio from 2002 to 2006 saw the largest decline in new auto purchases and residential investment during the Great Recession. Mian and Sufi (2010) also show that there is a strong relation between house price growth from 2006 to 2009 and the previous increase in household debt. As a result, while Mian and Sufi (2010) technically sort on an ex ante variable, it is best to view both the increase in $e x$ ante household debt and ex post house price decline as reflecting similar underlying shocks. Bunn and Rostom (2014) use microeconomic data on British households and find that individuals with higher debt had lower subsequent consumption growth after 2007. Andersen, Duus, and Jensen (2014) use individuial data on Danish households and find a strong negative correlation between pre-crisis leverage and the change in non-housing consumption during the crisis. Baker (2014) uses data from an online financial services firm and finds that highly indebted households in the United 
States during the Great Recession displayed a larger elasticity of consumption with respect to negative income shocks. All of these studies imply a close connection between consumption growth during recession and household balance sheets.

One concern with sorting individuals based on a shock received in the recession is that the decline in income of consumption could be related an omitted variable driving both the shock and the outcome of interest. For example, in Davis and von Wachter (2011), one worry is that the individuals laid off during a recession are lower quality workers, which partially explains the high earnings displacement. Or in Mian, Rao, and Sufi (2013), the worry is that some omitted variable drives both the collapse in house prices and the collapse in consumption in a given county. In the section below, we will extend the results in Mian, Rao, and Sufi (2013) and discuss why we believe this is unlikely to be the case. The studies examining college graduation are less exposed to this criticism given that the timing of college graduation is less likely to be driven by an omitted variable correlated with a recession occurring.

\subsection{Results from Quantitative Models}

As mentioned in the introduction, we focus in this review chapter on studies focusing on the crosssectional variation across individuals in consumption growth and income growth during recessions. There is a large body of research employing quantitative models and calibration to assess the importance of business cycle fluctuations, and the review chapter by Heathcote, Storesletten, and Violante (2009) covers these studies in detail. We did, however, want to highlight some of the empirical findings from this literature, as they are related to the core question of who bears the cost of recessions.

Storesletten, Telmer, and Yaron (2001) and Storesletten, Telmer, and Yaron (2004) use the PSID to make two main points. First, they argue that innovations to the idiosyncratic component of an individual's income process is highly persistent. And second, they argue that idiosyncratic earnings risk is counter-cyclical. They support these arguments with a number of results. For example, they show that the cross-sectional standard deviation of earnings increases substantially during recessions just as the cross-sectional mean of earnings falls. Further, they show that an age

cohort of individuals who have lived through more contractionary periods have higher cross-sectional 
dispersion in earnings even as they age. ${ }^{2}$ The authors use these facts to motivate a quantitative model where the welfare losses associated with business cycle fluctuations are substantially larger than those implied by Lucas (1987).

\subsection{Summarizing the Literature}

Appendix Table 1 summarizes the main points of each of the articles discussed above, detailing the data used, the outcome measure, the time period examined, the cross-sectional sort employed, and main findings. A few points emerge when looking at the research as a whole.

First, there remains a need for more panel data, especially when it comes to consumption. Of the studies reviewed, only two sort on ex ante characteristics, and then track consumption through a recession for the same units. One of these is based on county-level data, not individual level data. On this same point, we need more research detailing whether sorts on contemporaneous placement within the distribution biases results in a meaningful way. This related to the discussion in section 2.1 above about people moving into and out of groups.

Second, the results on consumption growth in recessions are mixed. Researchers using the CEX tend to find that consumption of the rich is more cyclical and falls more in the Great Recession. Researchers using the PSID find that the poor see substantial declines in consumption, and one study shows that the decline in the consumption rate is much larger for the poor than the rich. It is difficult to reconcile the different findings because different data are used and different points in the distribution are analyzed. It may be that the perfect consumption data (the analogous data of the SSA on income) would show the same non-monotonicity shown in Guvenen, Ozkan, and Song (2014) where the very rich see the largest decline in consumption, but the moderate rich see less of a decline than the poor.

Third, researchers that sort on shocks received in the recession find long-lasting effects. This is especially true when sorting on whether one loses a job in a recession.

\footnotetext{
${ }^{2}$ Guvenen, Ozkan, and Song (2014) use SSA data to argue that variance of idiosyncratic earnings shocks is not counter-cyclical. Instead, it is the left skewness of shocks that is strongly counter-cyclical.
} 


\subsection{Related Areas of Research}

There are two areas of research that are related to the core question of this chapter: consumption risk sharing and consumption inequality. We do not present a comprehensive review of these areas here, but we want to mention a few studies that are related to the issue of who bears recession risk. Full consumption risk sharing is the idea that an individual's consumption is insured against idiosyncratic shocks. Cochrane (1991) is one of the earliest contributions. He uses the PSID to test whether idiosyncratic shocks such as illness, unemployment, or forced moving affect consumption. He finds that involuntary job loss in particular has a large effect on consumption growth. However, given a limited sample, he concludes that "many of the variables examined here do not yield a robust rejection of the theory."

Attanasio and Davis (1996) examine how consumption responds across groups in response to changes in the hourly wage structure of U.S. workers in the 1980s. They note the "extreme scarcity of longitudinal data sources with high-quality information on both earnings and consumption ...". Given this problem, they instead construct synthetic panels of individuals based on earnings information from the Current Population Survey and consumption data from Consumer Expenditure Survey. They form groups of men based on age and education, and they examine how relative movements in wages for each group affects consumption growth during the 1980s. Their core finding, best illustrated in their Figure 2, shows a strong relation between relative wage movements and consumption growth. They conclude that their findings represent "a spectacular failure of between-group consumption insurance, a failure not explained by existing theories of informationally constrained optimal consumption behavior."

Schulhofer-Wohl (2011) argues that it is crucial to take into account heterogeneity in risk preferences when conducting tests of consumption risk sharing. For example, he shows that if less risk-averse households have more pro-cyclical incomes (as would be expected if individuals sort into occupations based in part on risk tolerance), standard tests of consumption risk sharing will tend to reject full risk sharing even if it is present. He uses the PSID to show that accounting for such heterogeneity leads to a failure to reject full consumption risk sharing.

Another related area of research is on the evolution of consumption inequality over the past 50 years in the United States. There is an enormous literature on this subject, which includes 
contributions by Slesnick (2001), Attanasio, Battistin, and Ichimura (2004), Krueger and Perri (2006), Heathcote, Perri, and Violante (2010), Aguiar and Bils (2015), Attanasio, Hurst, and Pistaferri (2012), and Meyer and Sullivan (2013b). For the purposes of this chapter, we want to highlight the data used and controversy regarding whether there in fact has been an increase in consumption inequality. The earlier studies in this literature found that consumption inequality measured using the CEX does not track the increase in income inequality. However, later studies argued that this may be due to reporting biases associated with the CEX. Attanasio, Hurst, and Pistaferri (2012) in particular make adjustments in the use of the CEX and look also at evidence from the PSID to find that consumption inequality did in fact rise over the past 30 years.

This debate was particularly fruitful because it helped researchers understand better the advantages and disadvantages of the CEX, which is the main data set on consumption used in the literature. Our approach in our own research has been to rely on administrative data collected by private companies. We will return to some of the issues associated with the CEX in the next section.

\section{$3 \quad$ Zip Code Level Consumption Measures}

\subsection{Toward administrative measures of consumption}

Following the discussion in Section 2.1, a key goal of empirical research in macroeconomic fluctuations is to estimate loadings on ex ante factors that predict the decline in consumption across individuals during economic downturns. Substantial progress has been made on the factors that predict a decline in income during recessions, in large part due to advances in the administrative data on earnings that has become recently available. But less progress has been made on consumption. They key limitation is the lack of individual-level panel data that very accurately measures consumption.

As noted above, researchers have primarily used data from two surveys: the CEX and the PSID. However, these two data sets have important limitations. First, neither data set is an ideal panel. The CEX data set only tracks the same individuals for four quarters, and the PSID is only conducted once every two years. This makes a comprehensive analysis of consumption growth during a recession difficult. 
Second, both data sets are based on surveys rather than administrative data. The CEX in particular has been criticized as a method for studying cross-sectional variation in consumption across individuals (e.g., Attanasio, Battistin, and Ichimura (2004), Cantor, Schneider, and Edwards (2011)). Studies have outlined many problems with the CEX, such as underreporting by high income households and a low response rate. Further, according to Cantor, Schneider, and Edwards (2011), these problems are becoming worse over time. ${ }^{3}$ More generally, there is an extensive body of showing non-classical error in measures of consumption using survey data. ${ }^{4}$ One of the most striking examples from the literature comes from Sweden. Koijen, Van Nieuwerburgh, and Vestman (2014) measure actual car purchases from registry data versus responses to a survey. They find underreporting in the survey of $30 \%$-that is, $30 \%$ of the households that actually buy a car do not report the purchase to the survey. This underreporting is worse for low income, poor, and older households.

To be clear, we are not saying we should never use survey-based measures of consumption. Adjustments to the measures can be made, or measurement errors may be less relevant for certain questions. However, we believe a promising avenue is to follow the income literature which increasingly relies on administrative data, such as the Social Security Administration data used in Guvenen, Ozkan, and Song (2014).

Some progress on this front has been made very recently. For example, Baker (2014) uses data from a large online personal finance website that connects users' financial accounts. Because the website has bank and credit card accounts, Baker (2014) can measure consumption using administrative data on transactions and withdrawals. Using these data, he finds that highly indebted households are more sensitive to income fluctuations. In particular, a one-standard deviation increase in the debt to asset ratio increases the elasticity of consumption by approximately $25 \%$. Two studies use administrative data from personal finance websites to study the effect of the 2013 government shutdown on consumption and borrowing (Baker and Yannelis (2015), Gelman, Kariv, Shapiro, Silverman, and Tadelis (2015)).

\footnotetext{
${ }^{3}$ The debate on the quality of CEX data is not settled. For example, Bee, Meyer, and Sullivan (2012) argue that the CEX performs well once adjustments are taken into account. Attanasio, Hurst, and Pistaferri (2012) argue that adjustments can be done to the CEX which makes cross-sectional comparisons across individuals more accurate. We do not wish to wade too deep into this debate; our goal is to point out that alternative measures of consumption can help.

${ }^{4}$ See for example the cites in Koijen, Van Nieuwerburgh, and Vestman (2014)
} 


\subsection{Zip code level data on consumption}

The approach we have used in our own research is to use administrative data that is aggregated by some geographical unit (Mian, Rao, and Sufi (2013)). We have utilized two measures: new auto sales at the zip code level from R.L. Polk, and purchases from debit card and credit card transactions at the county level from MasterCard Advisers. The county identified in the latter data set reflects the county of the store where items are purchased, not the county of residence of the buyer. Both of these data sets are based on actual transactions as opposed to survey responses. The R.L. Polk data are based on the universe of new vehicle registrations. The MasterCard data are limited to transactions where MasterCard is the servicer, but Mian, Rao, and Sufi (2013) show that aggregate spending using the MasterCard data closely tracks aggregate spending from Census retail sales.

In the work that follows we introduce three new measures of consumption. The first is also from R.L. Polk, and reflects the total number of vehicles registered to individuals living in a zip code. We have the total number of vehicles broken down by model year, which we use to depreciate the older vehicles using average used car prices reported in Jacobsen and van Benthem (2014). The final zip code level variable is the total number of vehicles in units of the current year (where older vehicles are depreciated before adding up to the total).

The second measure of consumption is registered recreational boats. The boat data come from Merchant Vessels of the United States, a data file of merchant and recreational vessels documented by the U.S. Coast Guard. Code of Federal Regulations (2001) requires any vessel of at least five net

tons which engages in the fisheries on the navigable waters of the United States or in the Exclusive Economic Zone, or coastwise trade to be registered each year, with some minor exemptions. Most vessels longer than 25 feet measure five net tons.

The data contain variables for the general service type of the vessel and the registration status. We take the number of all boats with recreational service type and valid registration to calculate the amount of boat consumption. Roughly $70 \%$ of vessels with valid registrations are recreational vessels in the data. We use the postal code of the managing owner's address to allocate boats to zip codes.

The third measure of consumption comes from the American Community Survey. The ACS 
provides zip code level statistics for every five year wave of surveys conducted. We use the 2005 to 2009 wave and the 2008 to 2012 wave. Two of the five years overlap (2008 and 2009), which will mechanically bias us away from finding large changes in a zip code. We refer to each wave by their midpoint year: the earlier wave is the 2007 wave and the later wave is the 2010 wave. The specific measure of consumption we use from this survey is the number of individuals over 16 per housing unit. We calculate the change in the number of adults living per housing unit from 2007 to 2010 as a measure of per capita consumption of housing services.

There is an additional measure we use that is better interpreted as a measure of welfare than consumption: the number of child births. We have this data set only for the state of California, which collects information on the number of births for residents of zip codes.

\subsection{Advantages and Disadvantages of Zip Code Level Data}

The main advantage of administrative zip code level data on consumption is that it is measured very well, and therefore closely tracks aggregates. For example, total new purchases of vehicles according to R.L. Polk almost perfectly matches total purchases according to Census retail sales. In an ideal world, we would be able to decompose aggregate macroeconomic consumption data into each individual. The zip code level administrative data sets are the closest we have at this point to this ideal. ${ }^{5}$

Relative to the ideal individual level panel data set, what are the disadvantages of using data at the zip code level? The first major disadvantage is that any aggregation procedure smooths differences across the population. If we are interested in how differences in ex ante factors or $e x$ post shocks affect consumption growth during recessions, we must have sufficient variation across zip codes to estimate parameters. The extent of this problem depends crucially on how people sort across zip codes. If, for example, there is a large degree of heterogeneity across individuals but no heterogeneity across zip code averages, then analysis using zip code level data has no variation to exploit. This would be the case if people randomly sorted across zip codes.

How big of a problem is this in the United States? As of 2000, there were 220 million individuals living in the United States over the age of 16, and approximately 31 thousand zip codes, which

\footnotetext{
${ }^{5}$ Baker (2014) shows that data he employs from a personal finance website closely tracks aggregates once weights are taken into account to adjust for differences in the characteristics of individuals who use the website.
} 
gives an average number of adults per zip code of about 7 thousand. However, the zip code level population is heavily skewed to the right. The median number of adults per zip codes is 2,225 and there are 21,732 at the 90 th percentile. There are 43,377 at the 99 th percentile.

How much variation do we lose by using zip code level data? To answer this question, we need data for some variable at both the individual level and zip code level. One important sorting variable in the literature is income. IRS data is available at both the individual level (in the public use file) and the zip code level. Figure 1 plots the distribution of the individual and zip code level data. For the zip code level data, we calculate the adjusted gross income per return, and then we look at points in the distribution when weighting by the total number of returns. As figure 1 shows, the zip code level distribution is smoothed, especially at the tails of the distribution. The 99th percentile in the individual level data is almost $\$ 400$ thousand. The 99th percentile zip code has an average AGI of $\$ 250$ thousand. But even with this smoothing, there is substantial variation in average income across zip codes.

The second potential problem is movers. This is the same criticism that applies to repeated cross-sectional analysis based on percentiles already discussed in Section 2.1, equation 3. Over long periods, people moving across zip codes presents a serious problem. It is not obvious how large a problem moving is when studying a two to three year window such as the Great Recession.

We are unaware of estimates that document the likelihood of people moving across zip codes during a two to three year period. The Census provides information on annual mover rates, which averaged $12.5 \%$ from 2006 to 2009 . However, most of these movers stayed within the same county. From 2006 to 2009, annual moving rate to another county was $3.9 \%$.

We do not yet have sufficient evidence to assess how moving across zip codes affects the crosssectional variation of consumption growth using zip code level data. For example, if movers tend to move to other zip codes that are similar based on the sorting variable in question, such movement may not be a concern. ${ }^{6}$

\footnotetext{
${ }^{6}$ The closest study we could find to answering this question is Yagan (2014) who examines whether workers bore the incidence of local labor demand shocks during the Great Recession even after they move to less affected areas. He finds that even workers that migrate to less impacted areas see "unusually small employment gains." This does not answer the key question we have in mind: do individuals that move end up in zip codes with a similar shock as the one they left.
} 


\section{Housing Net Worth Shock and the Great Recession}

In this section, we review and build on evidence on the importance of shocks to net worth coming from the collapse in house prices during the Great Recession. In particular, Mian, Rao, and Sufi (2013) show that variation across U.S. counties in the housing net worth shock - or the percentage decline in household net worth coming from the collapse in house prices - is correlated strongly with consumption growth. Using new measures of consumption at the zip code level, we build on this study and discuss possible interpretations of the results.

\subsection{Housing net worth shock: definition}

Following Mian, Rao, and Sufi (2013), we define the housing net worth shock in a zip code as:

$$
H N W \text { Shock }_{z} \equiv \frac{p_{z, 2009}-p_{z, 2006}}{p_{z, 2006}} * \frac{H_{z, 2006}}{F_{z, 2006}+H_{z, 2006}-D_{z, 2006}}
$$

where $p_{z, t}$ is the median price of an owner-occupied unit in zip code $z$ at time $t, H_{z, 2006}$ is the value of housing assets owned by residents in zip code $z$ in $2006, F_{z, 2006}$ is the value of financial assets held by residents in zip code $z$ in 2006, and $D_{z, 2006}$ is the book value of debt outstanding for residents of zip code $z$ in 2006. This definition follows from the decomposition of the percentage change in net worth from 2006 to 2009 , where we isolate the percentage change in net worth coming from the collapse in house prices. ${ }^{7}$

As definition 4 illustrates, the cross-sectional variation across zip codes in the housing net worth shock during the Great Recession is driven by two factors: house price growth in zip code $z$ during the Great Recession and the ex ante housing wealth to net worth ratio. The latter captures the effect of leverage. All else equal, zip codes that have more leverage have a higher housing wealth to net worth ratio. This amplifies the effect of house price growth on total net worth. Throughout, we define the housing wealth to total net worth ratio as the second term:

$$
\text { HousingWealthtoNetWorthRatio } z \equiv \frac{H_{z, 2006}}{F_{z, 2006}+H_{z, 2006}-D_{z, 2006}}
$$

As we show below, the housing wealth to net worth ratio is a strong predictor of consumption

\footnotetext{
${ }^{7}$ The exact methodology used to construct all variables in definition 4 is in Mian, Rao, and Sufi (2013).
} 
growth across zip codes during the Great Recession, with high housing wealth to net worth ratio zip codes seeing a larger decline in consumption.

The main sample restriction we must make is due to the fact that not all zip codes have accurate house price indices available. In particular, we use CoreLogic data on house prices, which cover approximately 6,600 of the 31,000 zip codes in the United States. These zip codes account for $65 \%$ of the adult population of the United States as of 2000. The main difference between zip codes with and without house price data is population density. The zip codes not in the sample are much more likely to be in rural areas. Rural areas do not have a sufficient number of housing transactions to construct house price indices.

In figure 2, we sort zip codes into five quintiles based on the housing net worth shock during the Great Recession. The quintiles are population-weighted, so each quintile contains the same number of people. We then plot the housing net worth shock across the distribution. By construction, the housing net worth shock is more negative in the lower quintiles.

Figure 2 shows a large degree of heterogeneity across zip codes in the United States in the housing net worth shock. In the first quintile, the collapse in house prices reduced household net worth by almost $30 \%$. In the fifth quintile, there is almost no change in household net worth coming from the collapse in house prices.

Table 1 shows summary statistics for the sample of zip codes. The summary statistics weight zip codes by total adult population as of 2000. As mentioned above, the housing net worth shock can be decomposed into house price growth from 2006 to 2009 and the housing wealth to net worth ratio as of 2006. As the summary statistics show, there is substantial variation across zip codes in both measures. The average housing wealth to net worth ratio is 0.46 , but it is 0.21 at the 10 th percentile and 0.77 at the 90 th percentile.

Table 1 also shows summary statistics for measures of consumption growth. There is a sharp decline in both new auto purchases and in the stock of vehicles during the Great Recession. Recall that our measure of registered autos depreciates older cars so that the units are in terms of new cars. The average number of adults per housing units declined by 0.016 from 2007 to 2010. The number of births fell sharply during the Great Recession. ${ }^{8}$

\footnotetext{
${ }^{8}$ For auto and boat registrations, we use 2006 to 2010 as the time period of examination. We do so because the registration data is not updated immediately, especially when registrations expire. For births, we use 2006 to 2010 under the assumption that parental decisions on births that are made in 2009 are realized in 2010.
} 


\subsection{Housing net worth shock and consumption growth}

Figures 3 and 4 show the strong correlation between consumption growth and the housing net worth shock across zip codes. Zip codes with the most negative housing net worth shock form 2006 to 2009 see a $20 \%$ decline in registered autos from 2006 to 2010 and a $50 \%$ decline in new auto purchases. For zip codes in the top quintile, the respective growth was $-10 \%$ and $-25 \%$.

Similar results are found in figure 4. Registered recreational boats fall more in zip codes with the most negative housing net worth shock. The number of adults living per housing unit increases the most in these same zip codes. The number of births also falls more in zip codes with the most negative housing net worth shock.

Table 2 presents estimates of the elasticity of consumption growth with respect to the housing net worth shock. Recall that the housing net worth shock is defined as the percentage decline in net worth coming from the collapse in house prices. The estimated elasticities are on the order of 0.2 to 0.8 depending on the measure of consumption. For births, the estimated elasticity is 0.12 .

The magnitude in column 5 requires additional information to interpret. Moving from the 90th to 10th percentile of the distribution of housing net worth shocks is a -0.25 movement. The coefficient estimate in column 5 implies such a move leads to a 0.04 increase in the number of adults living per housing unit. This may sound small, but the variation in the number of adults living per housing unit is also small-the standard deviation in the change in number of adults living per unit is only 0.095 , and so this effect is almost $1 / 2$ a standard deviation.

In table 3, we decompose the housing net worth shock from 2006 to 2009 into its two components: house price growth from 2006 to 2009 and the housing wealth to net worth ratio as of 2006. Panel A presents OLS estimates. The first column shows that the two components are strongly correlated: zip codes with a high housing weath to net worth ratio in 2006 experienced a larger decline in house prices during the Great Recession. The powerful correlation makes it difficult to separate the independent effects on consumption. The OLS estimates in columns 2 through 6 show that both components matter, especially for registered autos and new autos.

In panel B, we include county fixed effects in the estimation. This is useful because the majority of the variation in house price growth across zip codes is driven by county-level variation. ${ }^{9}$ For

\footnotetext{
${ }^{9}$ There are 1,021 counties in our sample, so an average of about 7 zip codes per county.
} 
example, the across-county standard deviation in house price growth from 2006 to 2009 is 0.13 whereas the within-county standard deviation is only 0.05 . This is a robust feature of house price variation in the United States - the majority of the variation is across county (or across city) as opposed to within county. In contrast, more of the variation in the housing wealth to net worth ratio as of 2006 is driven by within-county differences. The within-county standard deviation in the housing wealth to net worth ratio is 0.16 , whereas the across county standard deviation is 0.12 .

In an ideal setting, we could test whether the ex ante housing wealth to net worth ratio as of 2006 in a zip code predicts a stronger decline in consumption given an identical decline in zip code level house prices. In other words, we could hold the asset price shock constant, and estimate whether larger exposure to the shock has a strong effect on consumption growth.

Unfortunately, even with county fixed effects, house price growth and the housing wealth to net worth ratio are correlated. As column 1 of panel B shows, the regression coefficient remains negative and statistically significant when including county-fixed effects, but the coefficient is smaller with a smaller $t$ statistic. In columns 2 through 6 we include county fixed effects, and the results indicate a much stronger loading of consumption growth on the housing wealth to total net worth ratio as of 2006. That is, controlling for house price growth, zip codes with a larger share of net worth in housing see a bigger decline in consumption.

Figure 5 plots the fraction of homeowners underwater on their mortgage as of 2011 across the 2006 housing wealth to net worth ratio. As it shows, homeowners in zip codes with a higher housing wealth to net worth ratio as of 2006 were almost twice as likely to find themselves underwater on their mortgage when house prices fell.

\subsection{Exploring zip codes with high 2006 housing wealth to net worth ratio}

We have so far kept silent on the underlying economic mechanism connecting the 2006 housing wealth to net worth ratio to consumption growth during the Great Recession. Table 4 begins our discussion. Each cell in Table 4 is a regression coefficient from a separate regression of the 2006 housing wealth to net worth ratio on factors leading up to the Great Recession. The first column presents OLS estimates, and the second column presents county fixed effects specifications.

Zip codes with a higher housing wealth to net worth ratio as of 2006 experienced higher house price growth from 2002 to 2006 . The second row uses as a dependent variable the change in the 
cash-out refinancing share. This variable is defined as the average share of mortgages refinanced with cash taken out (i.e., the mortgage balance was increased) from 2003 to 2006 minus the average share from 2000 to 2002. As the coefficient estimates show, households with a high housing wealth to total net worth ratio as of 2006 saw a large increase in the share of mortgages refinanced with cash taken out from 2003 to 2006.

Figure 6 shows the result over time. We split the sample into five population-weighted quintiles based on the 2006 housing wealth to net worth ratio, and then plot the share of mortgages refinanced with cash out for the top and bottom quintile. There is a spike in cash-out refinancing in 2003 for both quintiles. But the share drops sharply for low ratio zip codes but remains elevated for high ratio zip codes through 2006. Starting in 2007, the cash-out refinancing share drops sharply for high ratio zip codes.

In Figure 7, we utilize individual level data from Equifax (described in detail in Mian and Sufi (2011)) to plot debt growth of existing homeowners. More specifically, we condition the sample on people who already owned their home in 1998, and then we plot total debt for the high and low 2006 housing net wealth to net worth ratio zip codes. It shows evidence consistent with Figure 6: existing homeowners borrowed much more aggressively against their homes during the housing boom, especially in 2005, 2006, and 2007.

Taken together, the evidence in Table 4, Figure 5, and Figure 7 supports the following narrative. Zip codes with a high 2006 housing wealth to net worth ratio in 2006 saw a large relative increase in house prices from 2002 to 2006, and a large increase in borrowing by homeowners. Figure 8 shows evidence that consumption growth was also higher from 2002 to 2006, which builds on evidence in Mian and Sufi (2014). New auto sales and registered autos increased by more in high housing wealth ratio zip codes during the housing boom, and then fell sharply during the recession. ${ }^{10}$

\subsection{Identification of house price effects}

Our preferred interpretation of the evidence is that cross-sectional variation in exogenous house price growth from 2002 to 2006 across zip codes drove the cross-sectional variation in debt growth and consumption growth by existing homeowners across zip codes. When house prices fell, households in

\footnotetext{
${ }^{10}$ ? use survey data on home equity withdrawal and car purchases, and they argue that cash extracted through home equity withdrawal was not directly used for car purchases. They investigate other channels for the correlation between cash-out refinancing and auto purchases.
} 
these same zip codes were forced to cut back sharply on consumption. The cut back in consumption was likely due to both an increased in desired savings and a tighter constraints on borrowing. This is the essence of the argument we have built in a series of studies (Mian and Sufi (2011), Mian, Rao, and Sufi (2013), Mian and Sufi (2014)).

It is crucial to note that the causal channel we have highlighted in our previous research is related to zip codes that saw both a boom and bust in house prices. A zip code level regression of house price growth from 2006 to 2009 on house price growth from 2002 to 2006 yields a negative coefficient with a $t$-statistic of 57 and an $R^{2}$ of 0.33 . In our view, it is difficult to exploit exogenous variation across zip codes in the collapse in house prices independent of the boom in house prices. The boom and bust should be considered together.

The primary concern with an interpretation in which house price movements were the causal factor is that the cross-sectional variation across zip codes in the house price boom and bust was due to omitted factors that may have simultaneously driven house prices, borrowing, and consumption patterns. The most worrisome alternative explanation in our view is a shock to permanent income or productivity during the early part of the 2000s differentially affecting zip codes where house prices rose the most that subsequently reversed during the Great Recession.

In an attempt to rule out such alternative explanations for the patterns we have shown above, our previous work has relied on instruments for cross-sectional variation in house price growth. In Mian and Sufi (2011), we use two instruments: one based on across MSA-variation and the other on within-MSA variation. The across-MSA instrument is housing supply elasticity of a city according to Saiz (2010). The logic behind this instrument is that there was a national shock to housing demand from 2002 to 2006 (driven by increased credit availability or stronger preferences for housing services). This national shock translated into higher house price growth in inelastic housing supply MSAs. The within-MSA instrument is based on the interaction of MSA housing supply elasticity and zip-code level credit scores. Mortgage originations for home purchase pushed up house prices disproportionately in low credit score neighborhoods, even though these neighborhoods saw no evidence of stronger wage or income growth.

The third and fourth row of Table 4 examine the regression coefficients of zip code level housing wealth to total net worth ratio as of 2006 on income growth from 2002 to 2006 . Echoing results from our previous research, there is no evidence of a contemporaneous positive income shock in 
these zip codes. In fact, income fell in relative terms in zip codes that saw the most house price growth and borrowing. ${ }^{11}$

The across-city housing supply elasticity instrument has been criticized by Davidoff (2013) and Davidoff (2014). In particular, Davidoff (2014) argues that supply constraints are correlated with demand growth. One implication of this argument is that perhaps the relative increase in borrowing and spending in inelastic housing supply cities during the 2002 to 2006 period was driven by differential demand shocks. Davidoff (2014) does not address the evidence in Mian and Sufi (2011) and Mian and Sufi (2014) that contemporaneous measures of permanent income shocks are uncorrelated with housing supply elasticity. Further, he does not address the within-city or within-county evidence that shows that borrowing and spending growth were strongest among zip codes within inelastic cities seeing a relative decline in observable measures of income growth. The results described above in Table 4 confirm this evidence: zip codes with the highest housing wealth to net worth ratio as of 2006 saw a relative decline in adjusted gross income and wage growth from 2002 to 2006, at the same time they were seeing the largest increase in borrowing and consumption of car services.

There are additional facts about high housing wealth to net worth ratio zip codes: they are poorer and have lower credit scores. The final two rows of Table 4 show that 2006 average adjusted gross income is lower in high housing wealth to net worth zip codes, and the fraction of individuals with a credit score below 660 was higher. These results are similar with or without county fixed effects. Figure 9 shows the relation between income and the housing wealth to net worth ratio. In zip codes in the highest quintile of the housing wealth to net worth ratio as of 2006, adjusted gross income was on average $\$ 40$ thousand. It was almost $\$ 90$ thousand in the lowest quintile.

This is important because many researchers sort on ex ante income or wealth when examining cross-sectional variation in consumption growth during the Great Recession. Lower consumption growth among low income individuals will reflect partially the differential effect of house price declines on low income individuals.

\footnotetext{
${ }^{11}$ In Mian and Sufi (2014), we also utilize an instrument proposed by Charles, Hurst, and Notowidigdo (2014) which is based on how quickly house prices accelerated in some cities during the 2000 to 2005 period.
} 


\section{$5 \quad$ Models Most Closely Related to these Facts}

The importance of housing and household debt in the Great Recession has spurred a large body of theoretical research exploring the interaction of houshold balance sheets and consumption. The first wave of macroeconomic models that most closely match the facts presented above are Eggertsson and Krugman (2012), Guerrieri and Lorenzoni (2015), Midrigan and Philippon (2011), and Huo and Ríos-Rull (2016).

In Guerrieri and Lorenzoni (2015), agents receive idiosyncratic uninsurable productivity shocks that generate a wealth distribution. There is a borrowing constraint households face, and households that have received the worst realization of productivity shocks end up closest to the constraint. The aggregate shock that precipitates a recession in the model is an exogenous tightening of the borrowing constraint. Such a tightening generates a decline in consumption across much of the distribution. Even unconstrained agents cut back on consumption when the constraint tightens due to a precautionary savings motive.

However, the drop in consumption is largest among households closest to the constraint. Guerrieri and Lorenzoni (2015) provide a figure showing heterogeneity in the consumption response depending on proximity to the constraint (Figure 6 in the current version). The most constrained agents cut consumption by more than $10 \%$, whereas the least constrained agents do not adjust consumption.

In Eggertsson and Krugman (2012), there are only two types of agents where an assumption on preferences generates the variation. Constrained agents have a low discount factor and consume up to their borrowing limit every year. Their consumption is therefore pinned down by the borrowing limit. Unconstrained agents lend to the constrained agents, and the interest rate governs their intertemporal consumption allocation decision.

As in Guerrieri and Lorenzoni (2015), the shock that generates the recession is a tightening of the borrowing constraint. In response to the tightening, the constrained agents cut back on consumption. If the interest rate is free to adjust, the unconstrained agents boost consumption as the interest rate falls. However, in the presence of nominal rigidities and the zero lower bound on nominal interest rates, the sharp decline in consumption of the constrained agents pushes the economy into recession. Once again, the key cross-sectional pattern in the model is that the decline 
in consumption is largest for the constrained agents.

How do these models relate to the empirical findings above? One interpretation is that the tightened borrowing constraint in the model reflects collapsing house prices during the Great Recession. Indeed, as Eggertsson and Krugman (2012) put it: "there are many reasons to expect the borrowing limit to depend to some extent on current condition, for example if the collateral value of the borrowers assets depend on current market conditions (such as the price of houses)...". Under this interpretation, the model prediction that the cut-back in consumption is largest in zip codes hardest hit by the house price collapse fits well with the data. Mian, Rao, and Sufi (2013) show that counties hit hard by the housing crash saw a larger decline in home equity loan availability, credit card limits, and mortgage refinancing volume.

In Midrigan and Philippon (2011), the key friction is a cash-in-advance constraint where both government-issued cash and private credit can be used by households to spend. Private credit for consumption must be collateralized by housing wealth, and the key parameter of interest is the fraction of housing wealth that can be borrowed against, which the authors call $\theta$. The authors introduce heterogeneity by having islands that start identical, but then receive differential positive shocks to their own $\theta$. The positive differential shocks to $\theta$ are meant to explain the differential rise in household debt during the housing boom. But then, $\theta$ reverts back to its pre-boom level, which generates a boom and bust on islands that saw the biggest rise and fall in the collateral constraint.

Midrigan and Philippon (2011) calibrate the model with assumptions on nominal rigidities, labor market rigidities, and collateral constraints that come from cross-sectional analysis of U.S. states during the Great Recession. Their key result is that states with a larger run-up in household debt see a bigger decline in consumption during the Great Recession.

Huo and Ríos-Rull (2016) build a model in which the fundamental shock is a tightening of financial conditions facing households. A key contribution of their study is a more serious consideration of housing wealth. In their model, the reduction in credit availability to households triggers a large drop in house prices, which then in turn depresses consumption. The model contains additional frictions sugh as difficulty in expanding production of tradable goods and labor market frictions preventing a dramatic decline in wages. In their model, the households that see the most negative consumption growth are those with most of their wealth tied up in housing. This is consistent with the patterns we have shown above, where the decline in consumption is largest in zip codes where 
housing wealth was a large fraction of total net worth prior to the recession.

A second wave of studies extends the above models to explain more broadly how excessive borrowing may lead to economic downturns. Korinek and Simsek (2014) begin with a framework similar to Eggertsson and Krugman (2012), with preference differences generating a set of borrowers and lenders. Borrowers can choose any level of debt in the initial period of the model, but then a borrowing constraint is imposed in the second period of the model. If the imposed borrowing constraint is sufficiently tight, borrowers must cut spending considerably, generating a similar crosssectional relation as in Eggertsson and Krugman (2012). Korinek and Simsek (2014) show that in the presence of nominal rigidities that generate aggregate demand externalities, borrowing in the initial period may be excessive relative to the optimum a social planner would choose.

The reasoning is that the severe cutback in consumption by borrowers in the second period generates a reduction in consumption by other individuals in the economy (the "aggregate demand externality") given the presence of nominal rigidities such as the zero lower bound on interest rates. Borrowers do not take into account their effect on the consumption of other individuals if the borrowing constraint is binding, which implies that they borrow more than is socially optimal in the initial period.

Farhi and Werning (2015) explore economies in which nominal rigidities are present in both goods and labor markets, and the economies are subject to the zero lower bound on nominal interest rates or fixed exchange rate regimes. They show in this setting that the distribution of wealth affects aggregate demand and output, and agents may borrow too much ex ante. They apply this framework to a number of situations including credit booms and capital flows into an open economy.

Justiniano, Primiceri, and Tambalotti (2014) build a quantitative model to show that an expansion in credit supply, as opposed to a loosening of borrowing constraints, is more consistent with house price and mortgage debt patterns witnessed from 2000 to 2006. In particular, an expansion in credit supply predicts an increase in house prices, an increase in mortgage debt to GDP ratios, a decline in interest rates, and a flat debt to collateral value ratio. However, Justiniano, Primiceri, and Tambalotti (2014) do not explore how the expansion in credit supply affects consumption. Favilukis, Ludvigsson, and Van Nieuwerburgh (2015) build a quantitative model to explore dynamics in house price movements, and find that the housing boom from 2000 to 2006 was due to 
the relaxation of financing constraints and a decline in the risk premium associated with housing assets.

The models described utilize as exogenous shocks an expansion or contraction in borrowing limits or credit supply, and then explore the effects of these shocks on consumption and the aggregate economy. They generate cross-sectional predictions in who should experience the biggest drop in consumption during recessions. However, their primary focus is explaining the decline in aggregate economic activity. In contrast, the recent study by Berger, Guerrieri, Lorenzoni, and Vavra (2015) is focused on what governs the individual consumption response to a change in house prices. The build a model in which households derive utility from both the consumption of non-housing goods and housing services and from bequeathing wealth to their children. They also face borrowing constraints and income uncertainty. Their main analytical result is to show that the individual elasticity of non-durable consumption to an unexpected and permanent change in house prices can be characterized by the following sufficient statistic:

$$
\eta_{i t}=\frac{\frac{d C_{i t}}{C_{i t}}}{\frac{d P}{P}}=M P C_{i t} *(1-\delta) * \frac{P * H_{i, t-1}}{C_{i t}}
$$

where $M P C_{i t}$ is the marginal propensity to consume out of transitory income shocks for individual $i$ at time $t, \delta$ is the depreciation rate of housing assets, $P$ is the price of housing (assumed to be constant prior to the shock), $H_{i, t-1}$ is the amount of housing assets held by individual $i$ at time $t-1$, and $C_{i t}$ is consumption of individual $i$ at time $t$. The authors provide evidence from the PSID that the marginal propensity to consume out of transitory shocks and housing asset holdings are not strongly correlated.

Equation 6 is derived in a partial equilibrium framework, and both sides of the equation depend on endogenous variables such as house price growth and the marginal propensity to consume. Nonetheless, it is a useful statistic for understanding the cross-sectional variation across individuals in consumption growth in response to the same decline in house prices. If one can isolate exogenous shocks to house price growth, then equation 6 implies that the effect on consumption growth will be larger for individuals with a larger marginal propensity to consume out of temporary income shocks and a higher housing wealth to consumption ratio.

Our zip code level data described above is insufficient to test this equation explicitly, because 
we cannot measure either the marginal propensity to consume out of housing wealth or total consumption for households living in a zip code. Nonetheless, the results shown in Tables 3 and 4 are broadly supportive of equation 6 . Panel B of Table 3 shows that consumption growth during the Great Recession was lower in zip codes with a high housing wealth to net worth ratio after controlling for house price growth. In other words, for the same decline in house prices, high housing wealth to net worth zip codes saw lower consumption growth.

While we cannot know for sure, it seems likely that zip codes with a high housing wealth to net worth ratio also have a high housing wealth to consumption ratio. Further, as Table 4 shows, high housing wealth to net worth ratio zip codes have lower income and lower credit scores. We know from a large body of research that lower income and lower credit score individuals have higher marginal propensities to consume and borrow out of income, borrowing availability, or house price shocks.

We look forward to more empirical research that explicitly tests the elasticity of consumption growth with respect to house price growth using the sufficient statistic approach of Berger, Guerrieri, Lorenzoni, and Vavra (2015). As a final note, while Berger, Guerrieri, Lorenzoni, and Vavra (2015) use a fully rational framework to derive equation 6 , it is useful to note that marginal propensities to consume may vary across the population due to behavioral biases such as hyperbolic discounting in addition to borrowing constraints (see Harris and Laibson (2001)).

\section{Aggregate Evidence on Household Debt}

The primary focus of this review chapter is on who bears the cost of aggregate economic downturns. However, the theoretical studies discussed above-in particular, Eggertsson and Krugman (2012), Guerrieri and Lorenzoni (2015), Farhi and Werning (2015), Huo and Ríos-Rull (2016), and Korinek and Simsek (2014)-have the additional implication that elevated household debt combined with a credit supply shock and nominal rigidities may precipitate recessions. That is, these studies have both cross-sectional and aggregate implications.

Testing whether elevated household debt and a collapse in house prices cause aggregate economic downturns is a difficult exercise. For example, Beraja, Hurst, and Ospina (2015) argue that inferences about the determinants of aggregate business cycles using cross-region variation is poten- 
tially misleading because aggregate shocks cannot always be identified in the cross-section. However, there is an increasing body of evidence that suggests a robust correlation between increases in household debt and subsequent economic growth. One approach is to look at cross-sectional variation across more aggregated geographical units, such as countries or states within a country. Figure 10 utilizes new state-level personal consumption expenditure data from the BEA, and it shows a very strong relation between house price growth and consumption growth across states during the Great Recession. The estimated elasticity is 0.21 , and has a $t$ statistic of 7 . There may be skepticism of whether we can interpret this relation as a causal effect. But previous research has attempted to isolate exogenous variation in the boom and bust in house prices, and it robustly predicts a boom and bust in household spending.

Similar analyses have been conducted across countries for the Great Recession. Glick and Lansing (2010) look across countries and find that "countries with the largest increases in household leverage tended to experience the fastest rises in house prices over the same period. These same countries tended to experience the biggest declines in household consumption once house prices started falling." An analysis by Leigh, Ignaz, Simon, and Topalova (2012) confirms these findings. They find that countries with a larger run-up in household debt fueled by house price growth from 2002 to 2006 see the largest decline in consumption during the bust. Further, they do a more systematic analysis of past episodes from 1980 to 2011, and they find that housing busts lead to a larger decline in consumption when a large run-up in private debt precedes the bust.

The evidence goes beyond the Great Recession. In a series of studies, Schularick and Taylor (2012), Jordà et al. (2013), Jordà et al. (2014), and Jordà, Schularick, and Taylor (2014) examine how growth in credit predicts financial crises and recession severity in a long historical panel of advanced countries. Schularick and Taylor (2012) estimate regressions showing that credit growth predicts financial crises, whereas Jordà et al. (2013) show that recessions preceded by a large run-up in credit tend to be more severe. Jordà, Schularick, and Taylor (2014) extends the work in these previous two studies using novel data splitting credit into household and firm debt. They find that mortgage debt and real estate booms predict financial crises in the post World War II era, and they find that recessions preceded by rapid growth in mortgage debt tend to be deeper with slower recoveries. Dell'Ariccia et al. (2012) examine the characteristics of sharp increases in the bank credit to GDP ratio across a panel of countries from 1970 to 2009, and present descriptive evidence 
on the nature of booms and whether they lead to busts or financial crises.

Perhaps the strongest evidence in support of the aggregate implications of the theoretical frameworks by Eggertsson and Krugman (2012), Guerrieri and Lorenzoni (2015), Farhi and Werning (2015), Huo and Ríos-Rull (2016), and Korinek and Simsek (2014) comes from Mian, Sufi, and Verner (2015). They show robust predictive power of increases in the household debt to GDP ratio on subsequent economic growth in a panel of 30 mostly advanced economies over the last 40 years. Further, they attempt to isolate credit supply driven increases in household debt, and show these credit supply-driven booms predict lower subsequent economic growth. The predictive power of household debt increases is strongest in economies with fixed exchange rate regimes, supporting the importance of nominal rigidities. They also show evidence of a global household debt cycle: increases in the global household debt to GDP ratio predict subsequent lower global output growth. ${ }^{12}$

\section{Conclusion}

Shocks to household net worth coming from the collapse in house prices was an important determinant of consumption growth during the Great Recession. Further analysis of this pattern reveals that exposure to the housing crash as of 2006, which we measure as the 2006 housing wealth to total net worth ratio, was an important driver of this relation. Our review of the existing literature shows that very few studies focus on exposure to housing shocks when discussing the cross-sectional variation across households in consumption growth over the business cycle. We believe that more work is needed. Studies using macroeconomic data at the country level over longer time horizons finds a robust relation between increases in household debt and subsequent economic downturns, which suggests that the strong relation between household balance sheets and output growth is present even outside the Great Recession.

We now have a solid body of theoretical work that can be used to motivate further empirical analysis of the effects of house prices and household debt on consumption. We believe the most important leap forward on these questions will be made if researchers are able to obtain admin-

\footnotetext{
${ }^{12}$ In contrast, Cecchetti et al. (2011) estimate country-level panel regressions relating economic growth from $t$ to $t+5$ to the level of government, firm, and household debt in year $t$. They use a longer window of five years because it "reduces the potential effects of cyclical movements and allows [them] to focus on the medium-term growth rate." They do not find strong evidence that the level of private debt forecasts growth.
} 
istrative panel data on consumer spending that mirrors the high quality panel income data from the Social Security Administration. As discussed in Mian, Rao, and Sufi (2013), estimating differences in the marginal propensity to consume out of income and wealth shocks requires high quality microeconomic data on consumption. Obtaining such high quality data is even more important given the increasing focus of research on differences in the population in the marginal propensity to consume. 


\section{References}

Mark Aguiar and Mark Bils. Has consumption inequality mirrored income inequality? American Economic Review, 105(9):2725-56, 2015.

Asger Lau Andersen, Charlotte Duus, and Thais Lærkholm Jensen. Household debt and consumption during the financial crisis: evidence from danish micro data. Technical report, Danmarks Nationalbank Working Papers, 2014.

Orazio Attanasio and Steven J Davis. Relative wage movements and the distribution of consumption. Journal of Political Economy, pages 1227-1262, 1996.

Orazio Attanasio, Erich Battistin, and Hidehiko Ichimura. What really happened to consumption inequality in the us? Technical report, National Bureau of Economic Research, 2004.

Orazio Attanasio, Erik Hurst, and Luigi Pistaferri. The evolution of income, consumption, and leisure inequality in the us, 1980-2010. Technical report, National Bureau of Economic Research, 2012 .

Scott R Baker. Debt and the consumption response to household income shocks. 2014.

Scott R Baker and Constantine Yannelis. Income changes and consumption: Evidence from the 2013 federal government shutdown. Available at SSRN 2575461, 2015.

Adam Bee, Bruce D Meyer, and James X Sullivan. The validity of consumption data: Are the consumer expenditure interview and diary surveys informative? Technical report, National Bureau of Economic Research, 2012.

Martin Beraja, Erik Hurst, and Juan Ospina. The aggregate implications of regional business cycles. 2015.

David Berger, Veronica Guerrieri, Guido Lorenzoni, and Joseph Vavra. House prices and consumer spending. Technical report, National Bureau of Economic Research, 2015.

Truman Bewley. The permanent income hypothesis: A theoretical formulation. Journal of Economic Theory, 16(2):252-292, 1977. 
Philip Bunn and May Rostom. Household debt and spending. Bank of England Quarterly Bulletin, page Q3, 2014.

David Cantor, Sid Schneider, and Brad Edwards. Redesign options for the consumer expenditure survey. Technical report, Westat, 2011.

Stephen G. Cecchetti, M S Mohanty, and Fabrizio Zampolli. The real effects of debt. BIS Working Paper, 2011.

KK Charles, Erik Hurst, and MJ Notowidigdo. Housing booms, labor market outcomes, and educational attainment. Technical report, University of Chicago Working Paper, 2014.

John H Cochrane. A simple test of consumption insurance. Journal of political economy, pages 957-976, 1991.

Barry Z Cynamon and Steven M Fazzari. Inequality, the great recession, and slow recovery. 2014.

Thomas Davidoff. Supply elasticity and the housing cycle of the 2000s. Real Estate Economics, 41 (4):793-813, 2013.

Thomas Davidoff. Supply constraints are not valid instrumental variables for home prices because they are correlated with many demand factors. Available at SSRN 2400833, 2014.

Steven J Davis and Till von Wachter. Recessions and the costs of job loss. Brookings Papers on Economic Activity, page 1, 2011.

Giovanni Dell'Ariccia, Luc Laeven, Deniz Igan, and Hui Tong. Policies for macrofinancial stability: How to deal with credit booms. IMF Staff Discussion Note, June 2012.

Gauti B Eggertsson and Paul Krugman. Debt, deleveraging, and the liquidity trap: A fisherminsky-koo approach*. The Quarterly Journal of Economics, 127(3):1469-1513, 2012.

Emmanuel Farhi and Iván Werning. A theory of macroprudential policies in the presence of nominal rigidities. Working Paper, 2015.

Jack Favilukis, Sydney C. Ludvigsson, and Stijn Van Nieuwerburgh. The macroeconomic effects of housing wealth, housing finance, and limited risk-sharing in general equilibrium. Working Paper, 2015. 
Michael Gelman, Shachar Kariv, Matthew D Shapiro, Dan Silverman, and Steven Tadelis. How individuals smooth spending: Evidence from the 2013 government shutdown using account data. Technical report, National Bureau of Economic Research, 2015.

Reuven Glick and Kevin J Lansing. Global household leverage, house prices, and consumption. FRBSF Economic Letter, 1, 2010.

Veronica Guerrieri and Guido Lorenzoni. Credit crises, precautionary savings, and the liquidity trap. 2015.

Fatih Guvenen, Serdar Ozkan, and Jae Song. The nature of countercyclical income risk. Journal of Political Economy, 122(3):621-660, 2014.

Christopher Harris and David Laibson. Hyperbolic discounting and consumption. In Forthcoming Proceedings of the 8th World Congress of the Econometric Society, 2001.

Jonathan Heathcote and Fabrizio Perri. Wealth and volatility. 2015.

Jonathan Heathcote, Kjetil Storesletten, and Giovanni L Violante. Quantitative macroeconomics with heterogeneous households. Annual Review of Economics, 1(1):319-354, 2009.

Jonathan Heathcote, Fabrizio Perri, and Giovanni L Violante. Unequal we stand: An empirical analysis of economic inequality in the united states, 1967-2006. Review of Economic dynamics, 13(1):15-51, 2010.

Mark Huggett. The risk-free rate in heterogeneous-agent incomplete-insurance economies. Journal of economic Dynamics and Control, 17(5):953-969, 1993.

Zhen Huo and José-Víctor Ríos-Rull. Financial frictions, asset prices, and the great recession. 2016.

Mark R Jacobsen and Arthur A van Benthem. Vehicle scrappage and gasoline policy. 2014.

Louis S Jacobson, Robert J LaLonde, and Daniel G Sullivan. Earnings losses of displaced workers. The American Economic Review, pages 685-709, 1993.

Òscar Jordà, Moritz Schularick, and Alan M. Taylor. When credit bites back. Journal of Money, Credit and Banking, 45(s2):3-28, 2013. ISSN 1538-4616. 
Òscar Jordà, Moritz Schularick, and Alan M. Taylor. Betting the house. Federal Reserve Bank of San Francisco Working Paper, 2014.

Òscar Jordà, Moritz Schularick, and Alan M Taylor. The great mortgaging: housing finance, crises, and business cycles. Technical report, National Bureau of Economic Research, 2014.

Alejandro Justiniano, Giorgio E Primiceri, and Andrea Tambalotti. Credit supply and the housing boom. 2014.

Lisa B Kahn. The long-term labor market consequences of graduating from college in a bad economy. Labour Economics, 17(2):303-316, 2010.

Greg Kaplan, Kurt Mitman, and Giovanni Violante. Consumption and house prices in the great recession: Model meets evidence. Working Paper, 2015.

Ralph Koijen, Stijn Van Nieuwerburgh, and Roine Vestman. Judging the quality of survey data by comparison with" truth" as measured by administrative records: Evidence from sweden. In Improving the Measurement of Consumer Expenditures. University of Chicago Press, 2014.

Anton Korinek and Alp Simsek. Liquidity trap and excessive leverage. Working Paper, 2014.

Tom Krebs. Job displacement risk and the cost of business cycles. American Economic Review, 97 (3):664-686, 2007.

Dirk Krueger and Fabrizio Perri. Does income inequality lead to consumption inequality? evidence and theory. The Review of Economic Studies, 73(1):163-193, 2006.

Per Krusell and Anthony A Smith. On the welfare effects of eliminating business cycles. Review of Economic Dynamics, 2(1):245-272, 1999.

Per Krusell, Toshihiko Mukoyama, Ayşegül Şahin, and Anthony A Smith. Revisiting the welfare effects of eliminating business cycles. Review of Economic Dynamics, 12(3):393-404, 2009.

Daniel Leigh, D Ignaz, John Simon, and Petia Topalova. Dealing with household debt. International Monetary Fund. World Economic Outlook, pages 89-124, 2012.

Robert E Lucas. Models of business cycles, volume 26. Basil Blackwell Oxford, 1987. 
Christopher J Malloy, Tobias J Moskowitz, and Annette Vissing-Jørgensen. Long-run stockholder consumption risk and asset returns. The Journal of Finance, 64(6):2427-2479, 2009.

N Gregory Mankiw and Stephen P Zeldes. The consumption of stockholders and nonstockholders. Journal of Financial Economics, 29(1):97-112, 1991.

Bruce D Meyer and James X Sullivan. Consumption and income inequality and the great recession. The American Economic Review, 103(3):178-183, 2013a.

Bruce D Meyer and James X Sullivan. Consumption and income inequality in the us since the 1960s. 2013b.

Atif Mian and Amir Sufi. Household leverage and the recession of 2007-09. IMF Economic Review, 58(1):74-117, 2010.

Atif Mian and Amir Sufi. House prices, home equitybased borrowing, and the us household leverage crisis. The American Economic Review, pages 2132-2156, 2011.

Atif Mian and Amir Sufi. House price gains and us household spending from 2002 to 2006. Technical report, National Bureau of Economic Research, 2014.

Atif Mian, Kamalesh Rao, and Amir Sufi. Household balance sheets, consumption, and the economic slump. The Quarterly Journal of Economics, 128(4):1687-1726, 2013.

Atif R Mian, Amir Sufi, and Emil Verner. Household debt and business cycles worldwide. Technical report, National Bureau of Economic Research, 2015.

Virgiliu Midrigan and Thomas Philippon. Household leverage and the recession. 2011.

Philip Oreopoulos, Till von Wachter, and Andrew Heisz. The short-and long-term career effects of graduating in a recession. American Economic Journal: Applied Economics, 4(1):1-29, 2012.

Jonathan A Parker and Annette Vissing-Jorgensen. The increase in income cyclicality of highincome households and its relation to the rise in top income shares. Technical report, National Bureau of Economic Research, 2010.

Fabrizio Perri and Joe Steinberg. Inequality and redistribution during the great recession. Technical report, Federal Reserve Bank of Minneapolis, 2012. 
Thomas Piketty and Emmanuel Saez. Income inequality in the united states, 1913-1998. The Quarterly Journal of Economics, 118(1):1-39, 2003.

Thomas Piketty and Emmanuel Saez. The evolution of top incomes: A historical and international perspective. The American Economic Review, pages 200-205, 2006.

Thomas Piketty and Gabriel Zucman. Capital is back: Wealth-income ratios in rich countries 1700-2010. The Quarterly Journal of Economics, 129(3):1255-1310, 2014.

Emmanuel Saez. Striking it richer: The evolution of top incomes in the united states (updated with 2013 preliminary estimates). 2015.

Emmanuel Saez and Gabriel Zucman. Wealth inequality in the united states since 1913: Evidence from capitalized income tax data. Technical report, National Bureau of Economic Research, 2014.

Albert Saiz. The geographic determinants of housing supply. The Quarterly Journal of Economics, 125(3):1253-1296, 2010.

Moritz Schularick and Alan M. Taylor. Credit booms gone bust: Monetary policy, leverage cycles, and financial crises, 1870-2008. American Economic Review, 102(2):1029-1061, 2012. doi: 10. 1257/aer.102.2.1029.

Sam Schulhofer-Wohl. Heterogeneity and tests of risk sharing. Journal of Political Economy, 119 (5):925-958, 2011.

Daniel T Slesnick. Consumption and social welfare: Living standards and their distribution in the United States. Cambridge University Press, 2001.

Kjetil Storesletten, Chris I Telmer, and Amir Yaron. The welfare cost of business cycles revisited: Finite lives and cyclical variation in idiosyncratic risk. European Economic Review, 45(7):1311$1339,2001$.

Kjetil Storesletten, Chris I Telmer, and Amir Yaron. Cyclical dynamics in idiosyncratic labor market risk. Journal of Political Economy, 112(3):695-717, 2004. 
Johannes Stroebel and Joseph Vavra. House prices, local demand, and retail prices. Technical report, National Bureau of Economic Research, 2014.

Daniel Sullivan and Till Von Wachter. Job displacement and mortality: An analysis using administrative data. The Quarterly Journal of Economics, 124(3):1265-1306, 2009.

Robert Topel. Specific capital, mobility, and wages: Wages rise with job seniority. Journal of Political Economy, pages 145-176, 1991.

Danny Yagan. Moving to opportunity? migratory insurance over the great recession. 2014. 


\section{Figure 1: Zip Code versus Individual Data: Distribution of 2006 Income}

This figure compares zip code level and individual level data on 2006 adjusted gross income from the IRS. For the zip code level distribution, we calculate the AGI per return for each zip code, and then we look at points on the distribution when weighting by the total number of returns in the zip code. As the figure shows, zip code level data smooth the distribution, and the smoothing is substantial at the tails of the distribution.

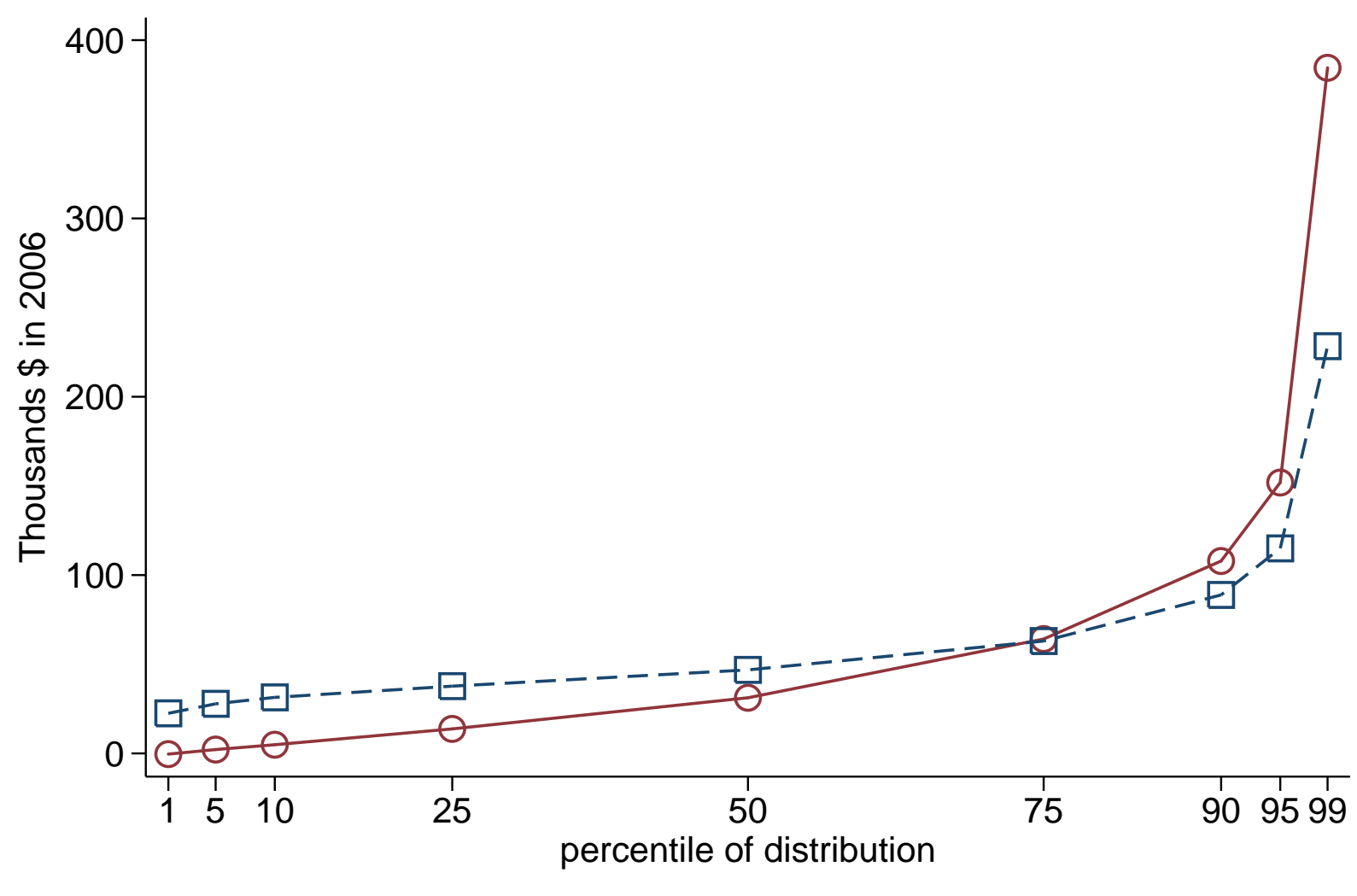

○ Individual level data $--\square--$ Zip level data 
Figure 2: Housing Net Worth Shock from 2006 to 2009 across Zip Codes

This figure plots the housing net worth shock across the housing net worth shock distribution. Each quintile contains $20 \%$ of the adult population.

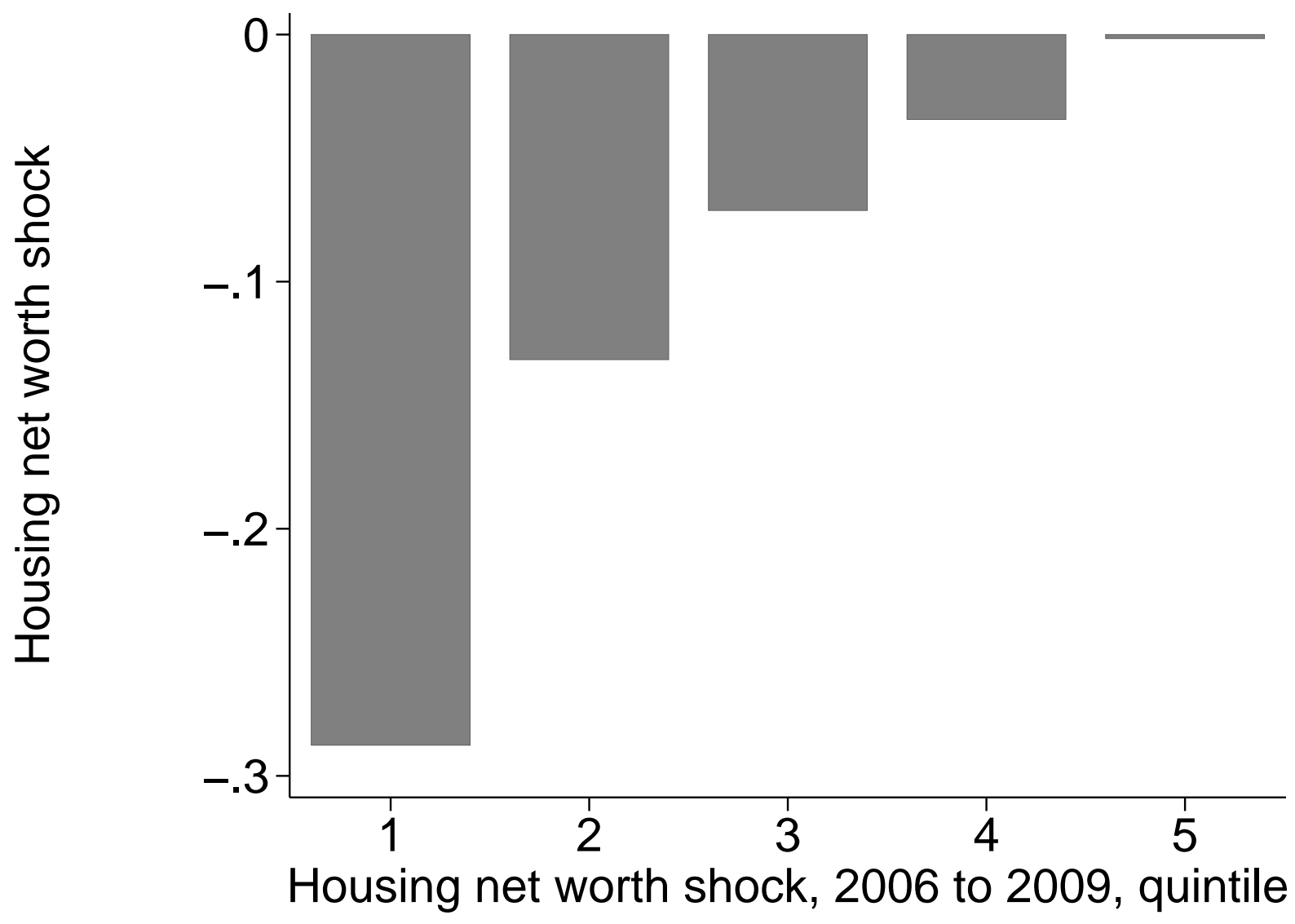


Figure 3: Housing Net Worth Shock from 2006 to 2009 and Consumption Growth

This figure plots measures of consumption growth across the housing net worth shock distribution. Each quintile contains $20 \%$ of the adult population.
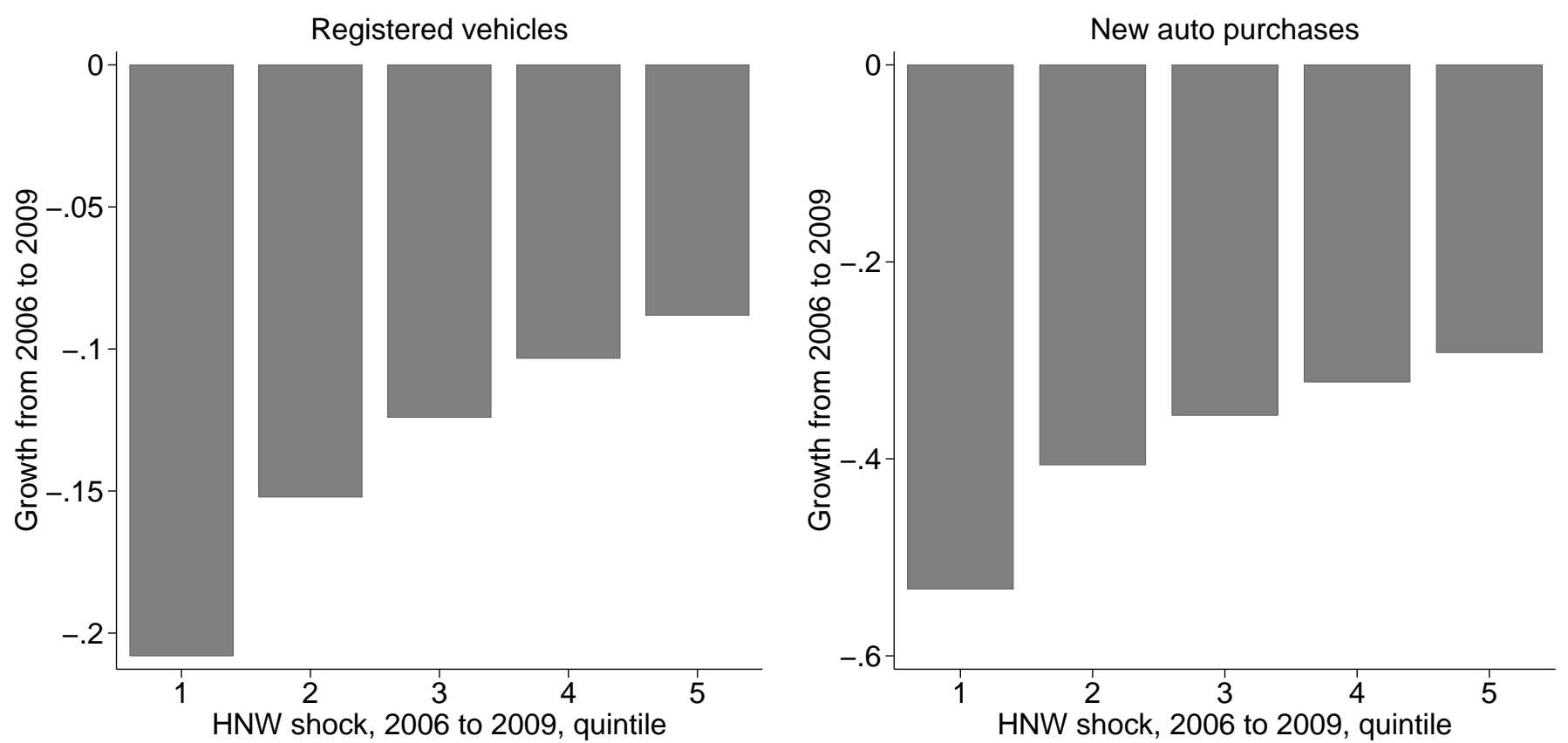
Figure 4: Housing Net Worth Shock from 2006 to 2009 and Other Measures of Consumption Growth

This figure plots recreational boats registered, the number of adults per housing unit, and births across the housing net worth shock distribution. Each quintile contains $20 \%$ of the adult population. Births are only available for California, and as a result we re-sort zip codes into quintiles based on California only for the right panel.
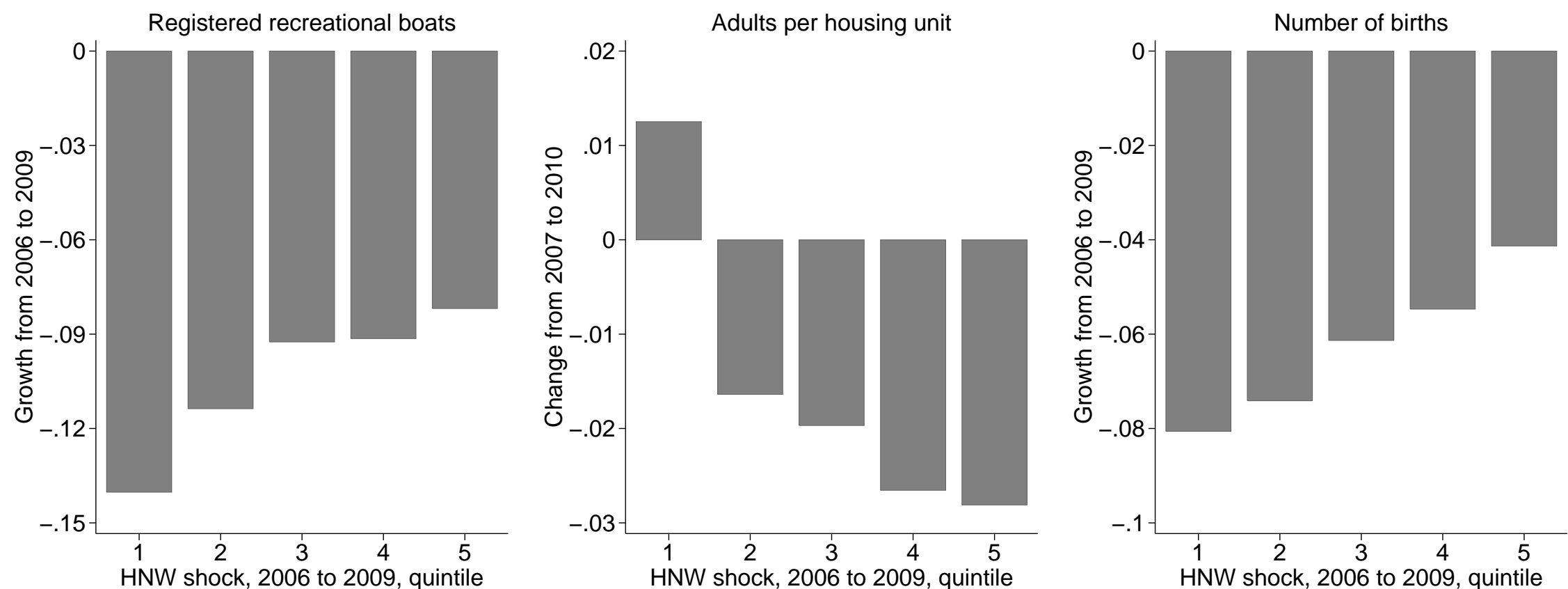
Figure 5: Housing Wealth to Net Worth Ratio and Underwater Homeowners

This figure plots the fraction of homeowners underwater in 2011 (total mortgage balance greater than the value of the home) across the distribution of the 2006 housing wealth to net worth ratio. Each quintile contains $20 \%$ of the population.

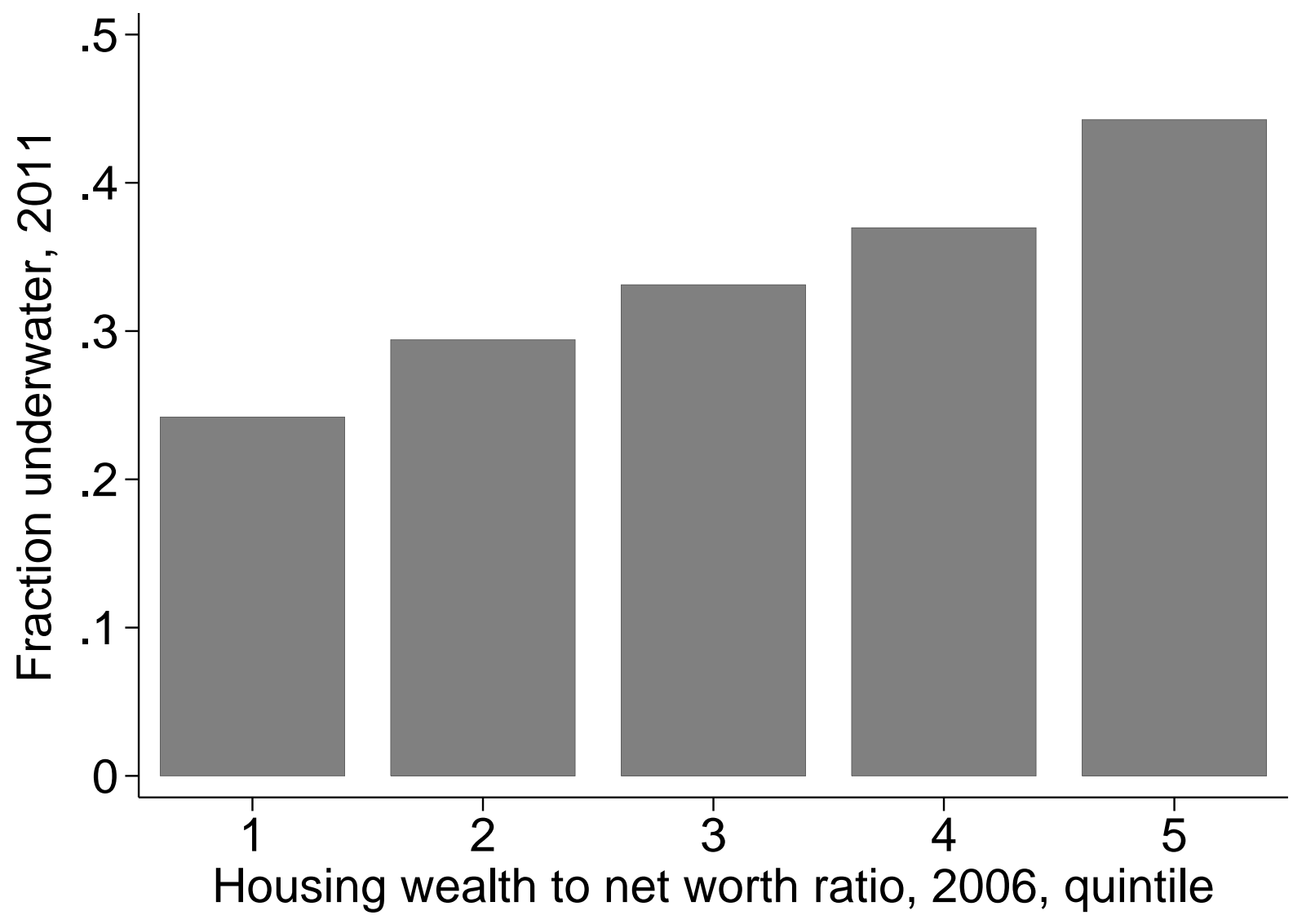


Figure 6: Cash Out Refinancing Share, by 2006 Housing Wealth to Net Worth Ratio

For this figure, we sort zip codes into population-weighted quartiles based on the 2006 housing wealth to net worth ratio. We plot the highest and lowest quartile below. The cash out refinancing share is the share of outstanding mortgages refinanced where cash is taken out in a given year.

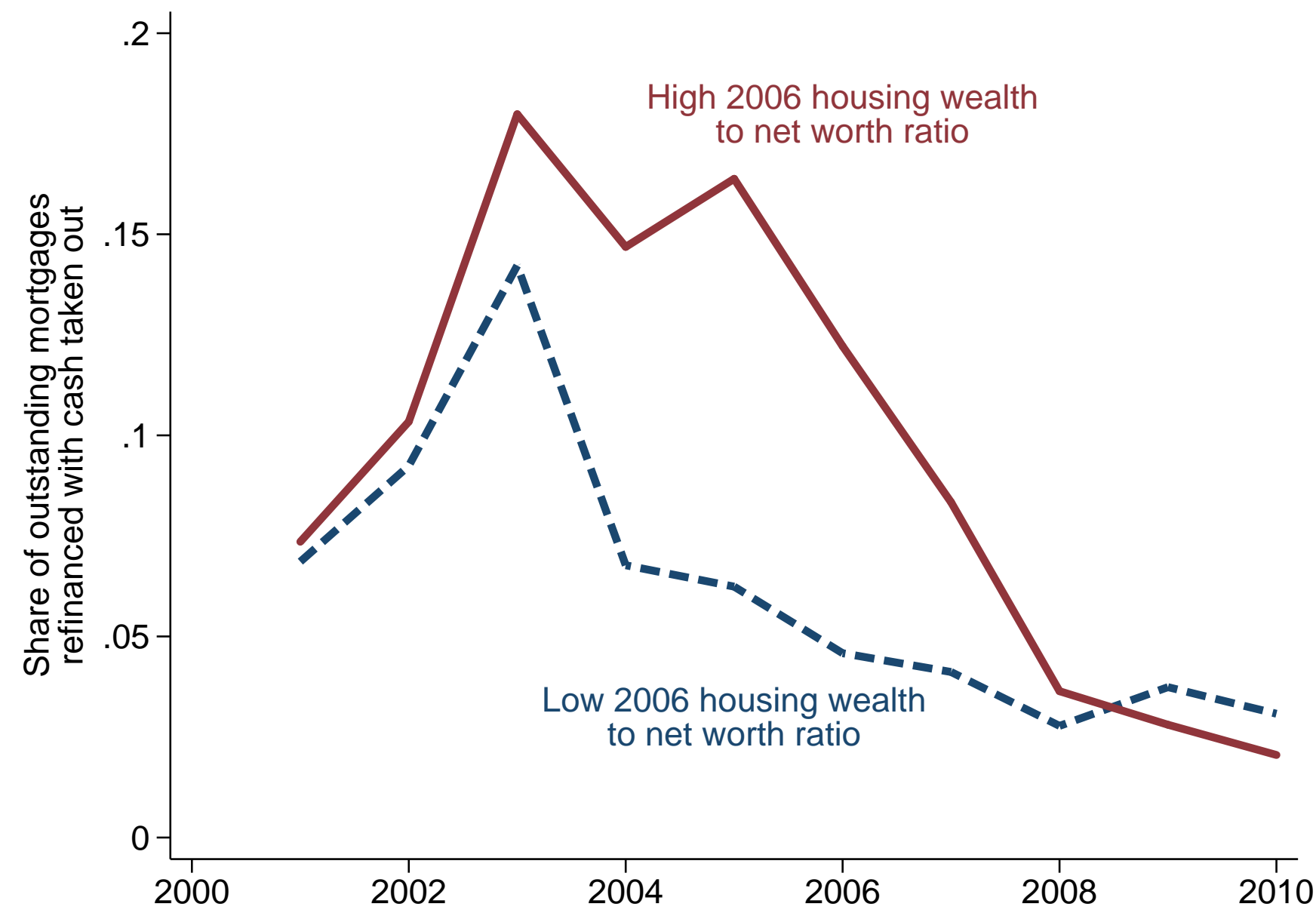


Figure 7: Total Debt of Homeowners, , by 2006 Housing Wealth to Net Worth Ratio

This figure uses individual-level data on people who were homeowners as of 1998. We sort individuals into groups based on the housing net worth to total net worth ratio of the zip code they live in 2006 . We then track total debt of homeowners in the top and bottom quartile.

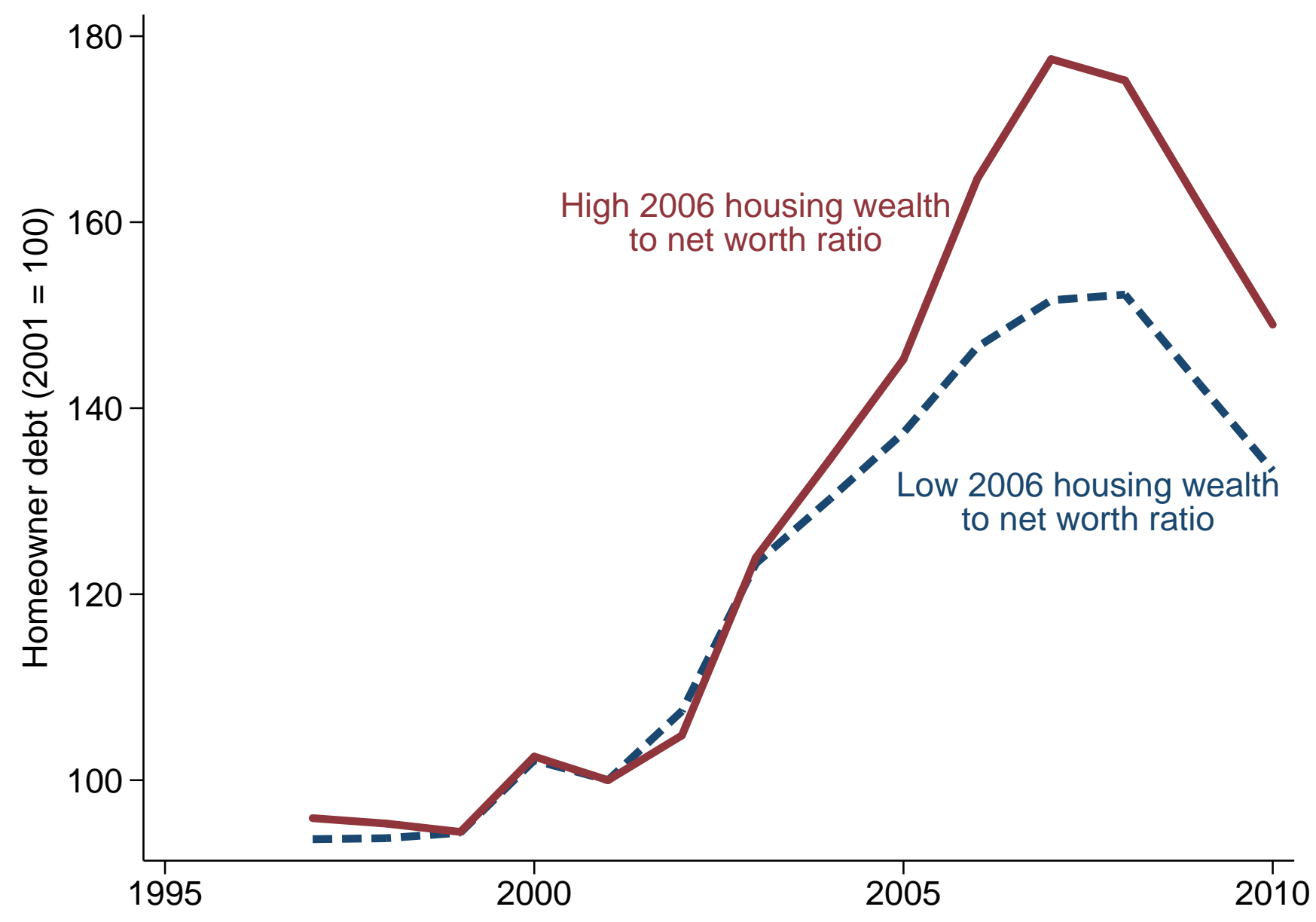


Figure 8: Consumption of Car Services, by 2006 Housing Wealth to Net Worth Ratio

For this figure, we sort zip codes into population-weighted quartiles based on the 2006 housing wealth to net worth ratio. We plot the highest and lowest quartile below.
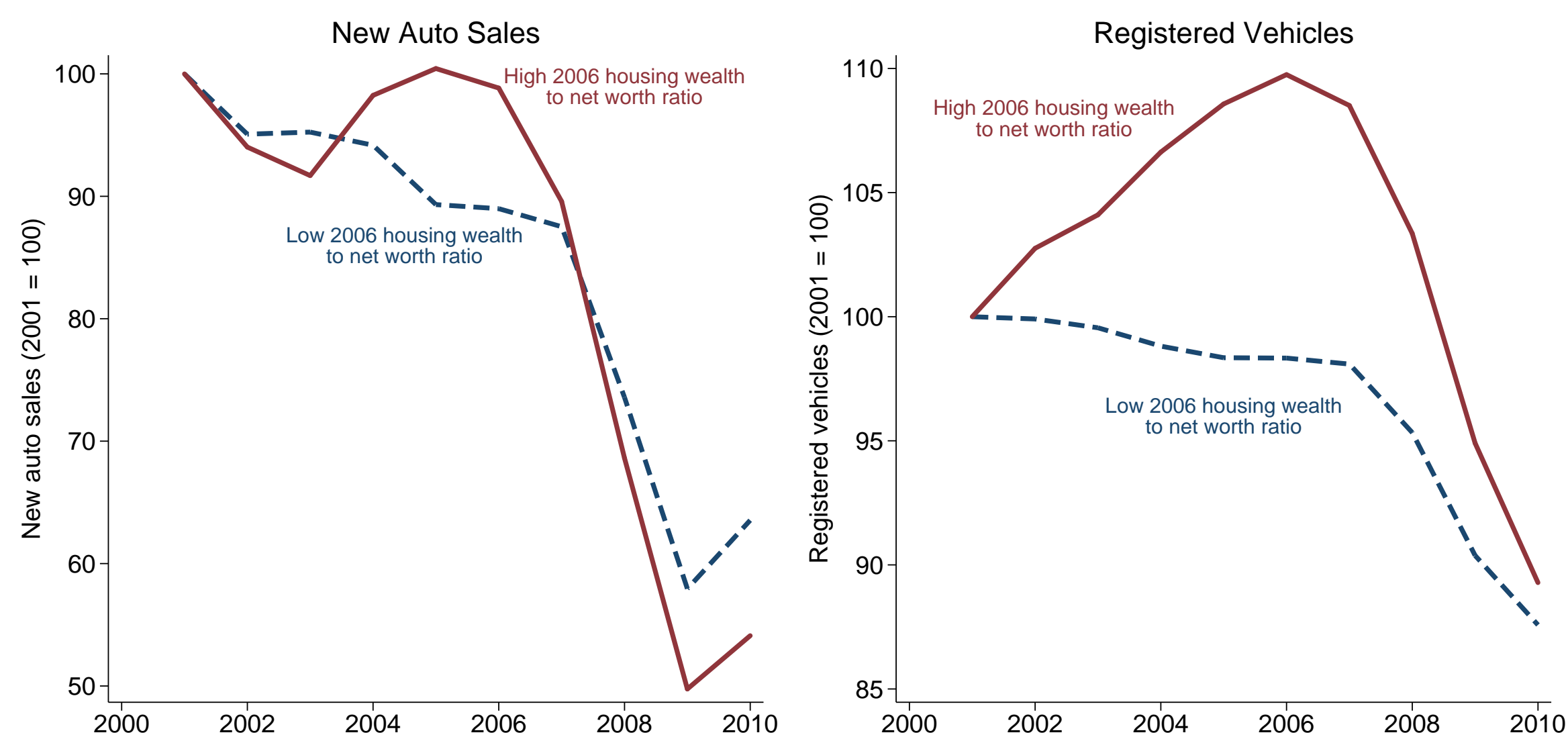
Figure 9: Average 2006 Income by 2006 Housing Wealth to Net Worth Ratio

This figure plots the average 2006 adjusted gross income across the housing wealth to net worth ratio distribution. Each quintile contains $20 \%$ of the adult population.

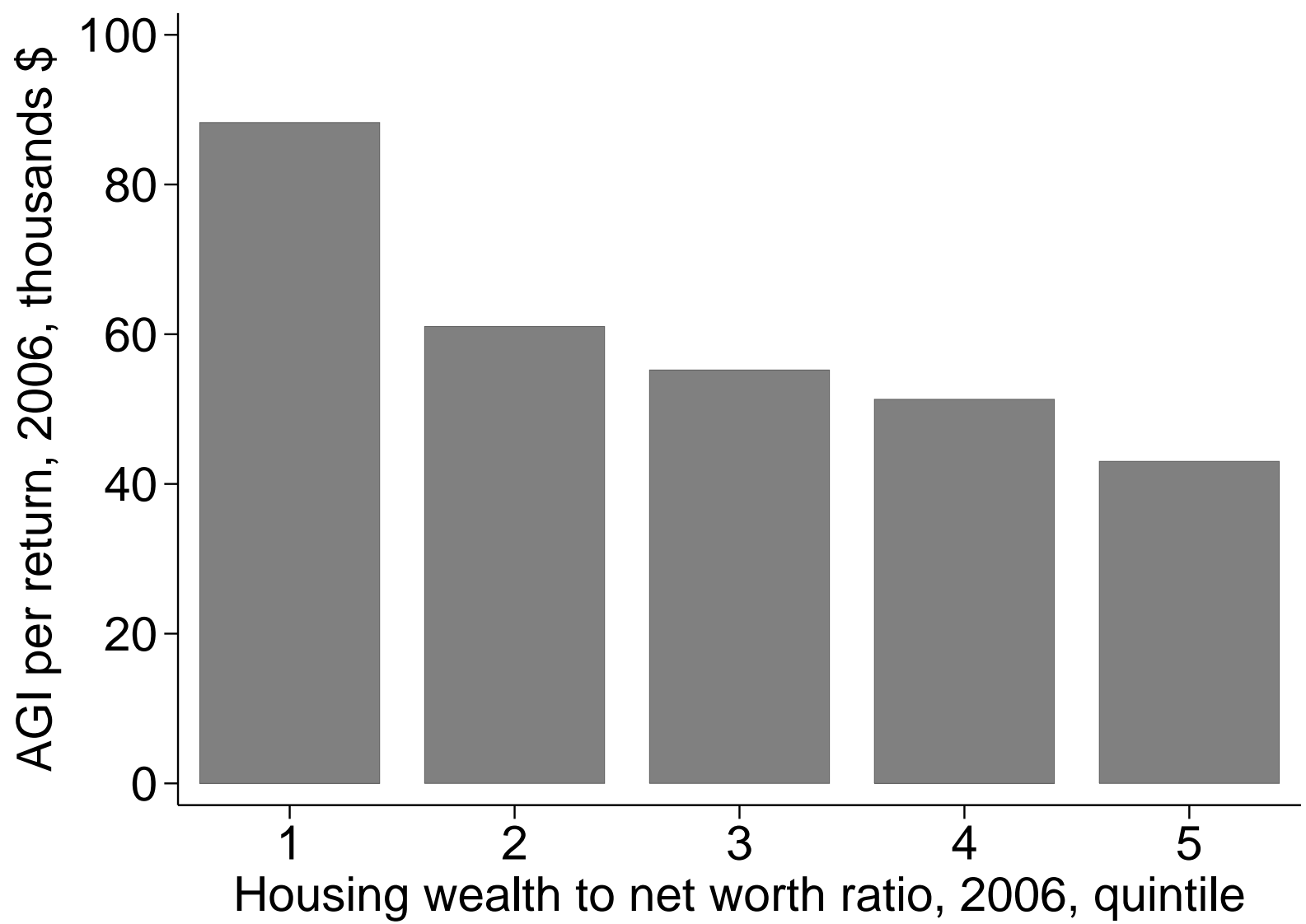


Figure 10: Consumption Growth and House Price Growth across States, 2006 to 2009

This figure plots consumption growth from 2006 to 2009 against house price growth from 2006 to 2009 for states. We use BEA state-level data on personal consumption growth and house price growth data from CoreLogic.

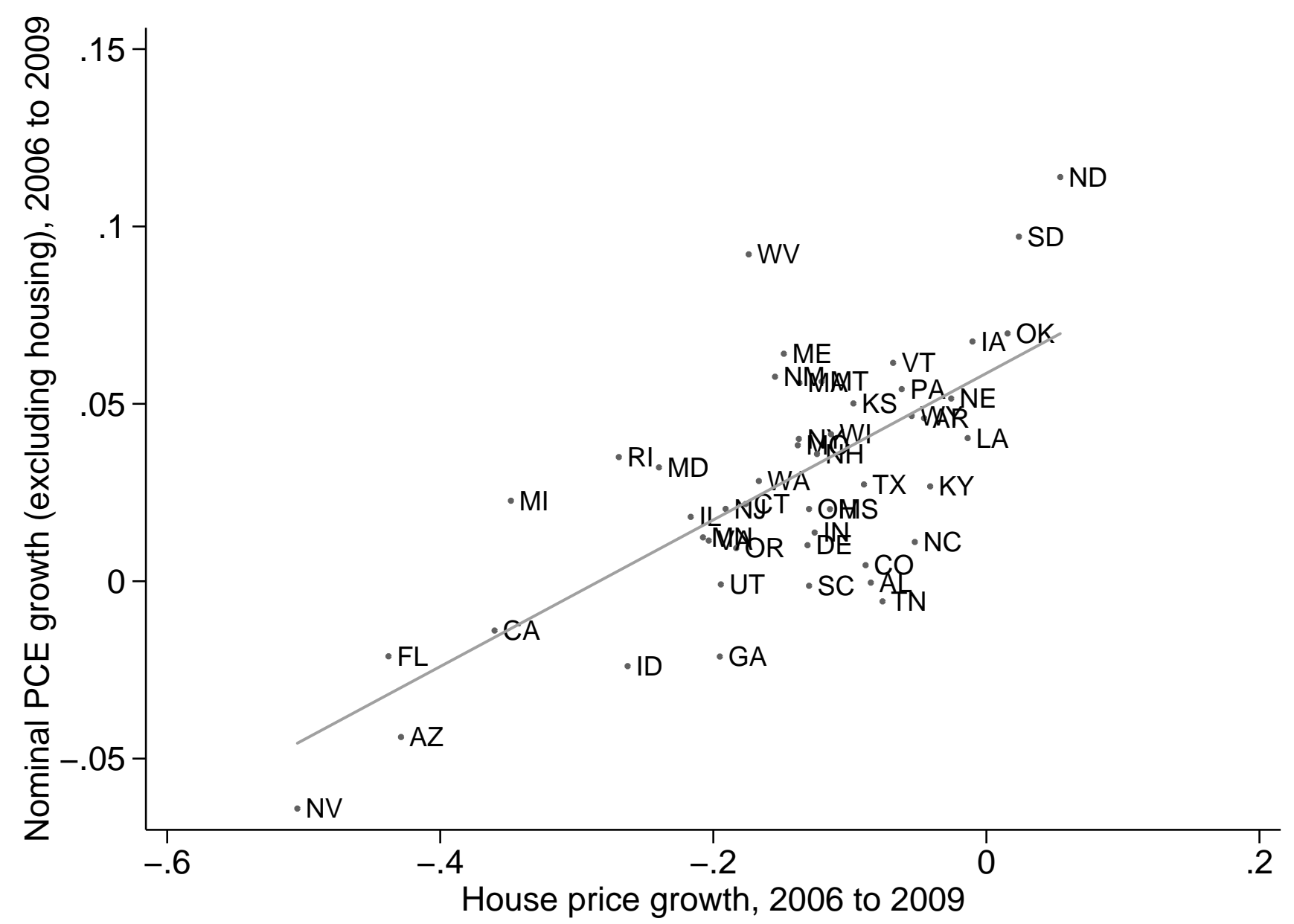


Table 1: Summary Statistics

This table presents summary statistics for zip codes in our sample. The sample is restricted to zip codes for which CoreLogic house price growth data are available. The housing net worth shock is the decline in net worth driven by the decline in house prices, or the product of house price growth from 2006 to 2009 and the 2006 housing wealth to net worth ratio. Registered autos reflect the total number of autos registered to residents of a zip code, where autos are depreciated according to their model year. Data on births are available only for California. For registered recreational boats, only zip codes with at least 10 registered boats in 2006 are included.

\begin{tabular}{lccccc}
\hline & & & & & \\
& $\mathrm{N}$ & Mean & $\mathrm{SD}$ & $10^{\text {th }}$ & $0^{\text {th }}$ \\
\hline Housing net worth shock & & & & & \\
Housing net worth shock, 2006 to 2009 & 6689 & -0.105 & 0.111 & -0.263 & -0.005 \\
Housing wealth to net worth, 2006 & 6689 & 0.456 & 0.218 & 0.212 & 0.767 \\
House price growth, 2006 to 2009 & 6689 & -0.200 & 0.153 & -0.430 & -0.017 \\
Outcomes & & & & & \\
Growth in autos registered, 2006 to 2010 & 6689 & -0.135 & 0.084 & -0.234 & -0.036 \\
Growth in new auto sales, 2006 to 2009 & 6689 & -0.382 & 0.149 & -0.582 & -0.199 \\
Change in adults per housing unit, 2007 to 2010 & 6686 & -0.016 & 0.095 & -0.125 & 0.091 \\
Growth in boats registered, 2006 to 2010 & 3204 & -0.102 & 0.196 & -0.348 & 0.150 \\
Growth in number of births, 2006 to 2010 & 855 & -0.087 & 0.106 & -0.202 & 0.038 \\
Fraction of homeowners underwater, 2011 & 6300 & 0.337 & 0.158 & 0.143 & 0.565 \\
Ex ante patterns & & & & & \\
House price growth, 2002 to 2006 & 6689 & 0.456 & 0.318 & 0.090 & 0.910 \\
Change in cash-out refinancing share & 6689 & 0.022 & 0.047 & -0.025 & 0.081 \\
Median household income, 2000 & 6689 & 48.705 & 16.657 & 31.031 & 70.821 \\
Wage growth, per tax return, 2002 to 2006 & 6689 & 0.106 & 0.068 & 0.030 & 0.189 \\
AGI growth, per tax return, 2002 to 2006 & 6689 & 0.186 & 0.124 & 0.064 & 0.345 \\
\hline
\end{tabular}


Table 2: Housing Net Worth Shock from 2006 to 2009 and Consumption Growth This table presents zip-code level regressions relating measures of consumption growth during the Great Recession to the housing net worth shock from 2006 to 2009. The housing net worth shock is the percentage decline in net worth coming from the collapse in house prices. Births are only available for California. Standard errors are clustered by county.

\begin{tabular}{lccccc}
\hline & $(1)$ & $(2)$ & $(3)$ & $(4)$ & $(5)$ \\
& $\begin{array}{c}\text { Registered } \\
\text { auto growth } \\
06 \text { to 09 }\end{array}$ & $\begin{array}{c}\text { New Auto } \\
\text { sales growth } \\
06 \text { to 09 }\end{array}$ & $\begin{array}{c}\text { Registered } \\
\text { boat growth } \\
06 \text { to 09 }\end{array}$ & $\begin{array}{c}\text { Adults per } \\
\text { unit change } \\
06 \text { to 09 }\end{array}$ & $\begin{array}{c}\text { Births growth } \\
06 \text { to 09 }\end{array}$ \\
\hline Housing net worth shock, 06 to 09 & $0.381^{* *}$ & $0.788^{* *}$ & $0.239^{* *}$ & $-0.150^{* *}$ & $0.116^{* *}$ \\
& $(0.019)$ & $(0.030)$ & $(0.052)$ & $(0.036)$ & $(0.026)$ \\
Constant & $-0.095^{* *}$ & $-0.299^{* *}$ & $-0.080^{* *}$ & $-0.031^{* *}$ & $-0.035^{* *}$ \\
& $(0.003)$ & $(0.006)$ & $(0.007)$ & $(0.003)$ & $(0.009)$ \\
\hline Observations & 6689 & 6689 & 3204 & 6686 & 856 \\
$\mathrm{R}^{2}$ & 0.250 & 0.342 & 0.012 & 0.031 & 0.027 \\
\hline
\end{tabular}


Table 3: Decomposition of Housing Net Worth Shock Effect on Consumption Growth

This table presents zip-code level regressions relating measures of consumption growth during the Great Recession to the components of the housing net worth shock: the 2006 house wealth to net worth ratio and house price growth from 2006 to 2009. Births are only available for California. Panel B includes county fixed effects. Standard errors are clustered by county.

\begin{tabular}{|c|c|c|c|c|c|c|}
\hline & $\begin{array}{c}(1) \\
\text { House price } \\
\text { growth } \\
06 \text { to } 09\end{array}$ & $\begin{array}{c}(2) \\
\text { Registered } \\
\text { auto growth } \\
06 \text { to } 09\end{array}$ & $\begin{array}{c}\text { Panel A: OLS } \\
(3) \\
\text { New Auto } \\
\text { sales growth } \\
06 \text { to } 09\end{array}$ & $\begin{array}{c}(4) \\
\text { Registered } \\
\text { boat growth } \\
06 \text { to } 09\end{array}$ & $\begin{array}{c}(5) \\
\text { Adults per } \\
\text { unit change } \\
06 \text { to } 09\end{array}$ & $\begin{array}{c}(6) \\
\text { Births growth } \\
06 \text { to } 09\end{array}$ \\
\hline House wealth to net worth, 2006 & $\begin{array}{c}-0.297^{* *} \\
(0.022)\end{array}$ & $\begin{array}{c}-0.034^{*} \\
(0.013)\end{array}$ & $\begin{array}{c}-0.147^{* *} \\
(0.022)\end{array}$ & $\begin{array}{l}-0.019 \\
(0.021)\end{array}$ & $\begin{array}{l}0.061^{* *} \\
(0.015)\end{array}$ & $\begin{array}{c}-0.057^{* *} \\
(0.014)\end{array}$ \\
\hline House price growth, 06 to 09 & & $\begin{array}{c}0.274^{* *} \\
(0.020)\end{array}$ & $\begin{array}{c}0.464^{* *} \\
(0.034)\end{array}$ & $\begin{array}{c}0.147^{* *} \\
(0.037)\end{array}$ & $\begin{array}{l}-0.031 \\
(0.028)\end{array}$ & $\begin{array}{c}0.054 \\
(0.037)\end{array}$ \\
\hline Constant & $\begin{array}{c}-0.064^{* *} \\
(0.011)\end{array}$ & $\begin{array}{c}-0.065^{* *} \\
(0.004)\end{array}$ & $\begin{array}{c}-0.222^{* *} \\
(0.008)\end{array}$ & $\begin{array}{c}-0.064^{* *} \\
(0.010)\end{array}$ & $\begin{array}{c}-0.050^{* *} \\
(0.006)\end{array}$ & $\begin{array}{l}-0.007 \\
(0.016)\end{array}$ \\
\hline \multirow[t]{2}{*}{$\begin{array}{l}\text { Observations } \\
\mathrm{R}^{2}\end{array}$} & $\begin{array}{c}6689 \\
0.179\end{array}$ & $\begin{array}{r}6689 \\
0.291\end{array}$ & $\begin{array}{c}6689 \\
0.360\end{array}$ & $\begin{array}{l}3204 \\
0.013\end{array}$ & $\begin{array}{c}6686 \\
0.029\end{array}$ & $\begin{array}{c}856 \\
0.033\end{array}$ \\
\hline & $\begin{array}{c}(1) \\
\text { House price } \\
\text { growth } \\
06 \text { to } 09\end{array}$ & $\begin{array}{c}\text { Panel B } \\
(2) \\
\text { Registered } \\
\text { auto growth } \\
06 \text { to } 09\end{array}$ & $\begin{array}{c}\text { County Fixec } \\
\qquad(3) \\
\text { New Auto } \\
\text { sales growth } \\
06 \text { to } 09\end{array}$ & $\begin{array}{l}\text { Effects } \\
\qquad(4) \\
\text { Registered } \\
\text { boat growth } \\
06 \text { to } 09\end{array}$ & $\begin{array}{c}(5) \\
\text { Adults per } \\
\text { unit change } \\
06 \text { to } 09\end{array}$ & $\begin{array}{c}(6) \\
\text { Births growth } \\
06 \text { to } 09\end{array}$ \\
\hline House wealth to net worth, 2006 & $\begin{array}{c}-0.090^{* *} \\
(0.010)\end{array}$ & $\begin{array}{c}-0.073^{* *} \\
(0.008)\end{array}$ & $\begin{array}{c}-0.219^{* *} \\
(0.018)\end{array}$ & $\begin{array}{c}-0.087^{* *} \\
(0.026)\end{array}$ & $\begin{array}{c}0.063^{* *} \\
(0.012)\end{array}$ & $\begin{array}{c}-0.051^{* *} \\
(0.013)\end{array}$ \\
\hline House price growth, 06 to 09 & & $\begin{array}{c}0.093^{* *} \\
(0.021)\end{array}$ & $\begin{array}{c}0.230^{* *} \\
(0.036)\end{array}$ & $\begin{array}{c}0.150 \\
(0.091)\end{array}$ & $\begin{array}{l}-0.052^{*} \\
(0.023)\end{array}$ & $\begin{array}{c}0.017 \\
(0.037)\end{array}$ \\
\hline $\begin{array}{l}\text { Observations } \\
\mathrm{R}^{2}\end{array}$ & $\begin{array}{c}6689 \\
0.893\end{array}$ & $\begin{array}{c}6689 \\
0.556\end{array}$ & $\begin{array}{c}6689 \\
0.686\end{array}$ & $\begin{array}{l}3204 \\
0.258\end{array}$ & $\begin{array}{r}6686 \\
0.443\end{array}$ & $\begin{array}{c}856 \\
0.128\end{array}$ \\
\hline
\end{tabular}

$* *, *$ Coefficient statistically different than zero at the $1 \%$ and $5 \%$ confidence level, respectively. 
Table 4: Understanding Variation in 2006 Housing Wealth to Net Worth Ratio

This table presents coefficients from zip-code level univariate regressions of the housing wealth to net worth ratio in 2006 on various zip code level characteristics. Each cell is from a separate regression. The regression specifications in column 2 include county fixed effects. Standard errors are clustered by county.

\begin{tabular}{lcc}
\hline & \multicolumn{2}{c}{ Housing wealth to net worth ratio, 2006 } \\
\cline { 2 - 3 } & $(1)$ & $(2)$ \\
\hline House price growth, 2002 to 2006 & $0.313^{* *}$ & $0.499^{* *}$ \\
& $(0.041)$ & $(0.106)$ \\
$\Delta$ Cash-out refinancing share & $2.495^{* *}$ & $3.894^{* *}$ \\
Wage growth, 2002 to 2006 & $(0.271)$ & $(0.205)$ \\
& $-0.626^{* *}$ & $-1.179^{* *}$ \\
AGI growth, 2002 to 2006 & $(0.071)$ & $(0.090)$ \\
& $-0.825^{* *}$ & $-1.078^{* *}$ \\
Ln(Adjusted gross income, 2002) & $(0.038)$ & $(0.051)$ \\
& $-0.244^{* *}$ & $-0.339^{* *}$ \\
Fraction subprime, 2002 & $(0.025)$ & $(0.014)$ \\
& $0.702^{* *}$ & $0.957^{* *}$ \\
County Fixed Effects & $(0.075)$ & $(0.057)$ \\
\hline
\end{tabular}

**,* Coefficient statistically different than zero at the $1 \%$ and $5 \%$ confidence level, respectively. 